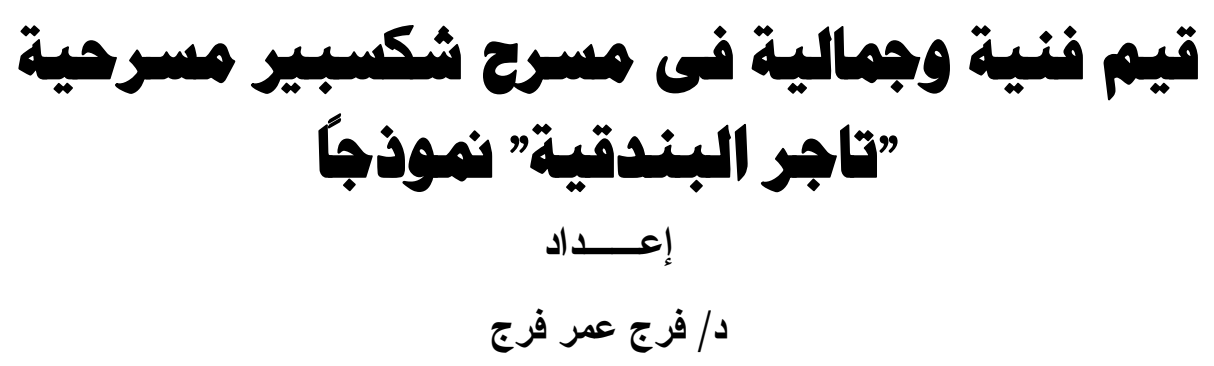

مدرس الإعلام والدراما و النقد بكلية التربية النوعية - جامعة المنوفية

ملخص الار اسة

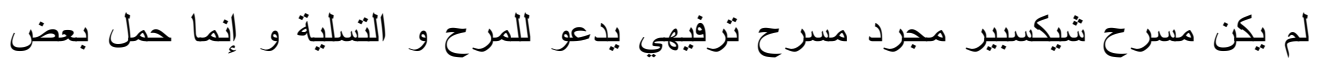

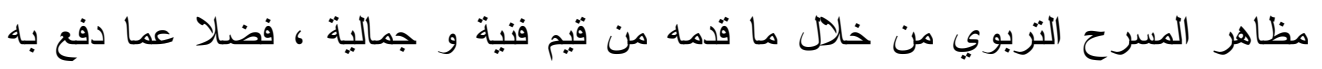

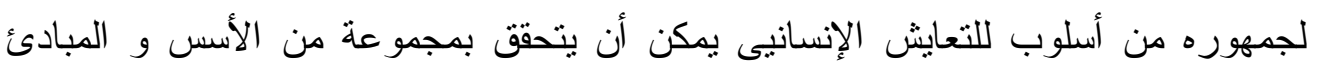

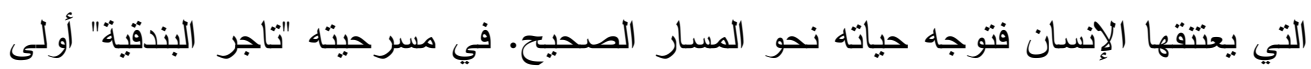

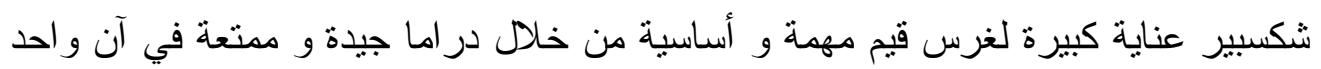

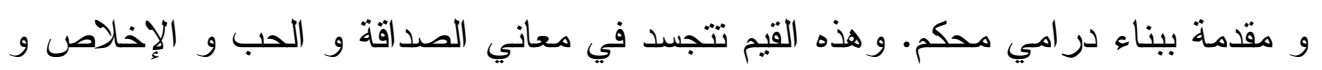

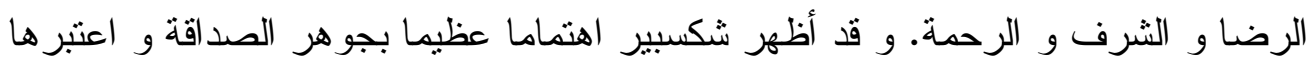

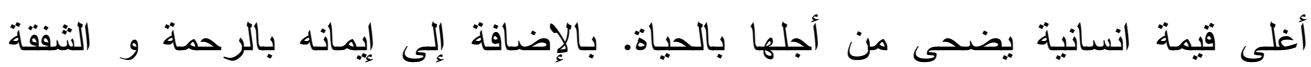
باعتبار هما طريقين يسلكهما البشر من أجل سيادة قيم عليا تحكم الحياة الإنسانية.

\title{
Summery of the study
}

The theatre of Shakespeare was not mere entertaining theatre, but it has educational symptoms conveying artistic and aesthetic values. It teaches us how to live together as real human being through that basis and principals which direct one's life. In his play "Merchant of Venice", Shakespeare was very keen to offer his audience several important and essential values through serious and enjoyable drama with perfect dramatic structure. These values like: friendship, love, faith, satisfaction, honor and mercy. He gave a great care to them essence of friendship and love as being the most precious values in the life. In addition to this he believes that mercy and pity should dominate all the human relation. 
المعروف أن" الدراما تمثل نموذجاً نقياً للمحادثة الاجتماعية ، ويقترب الحوار على

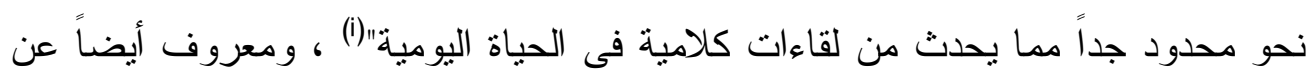
وليم شكسبير أنه "يروع عقول البشر بقوة حواره وعمق غوصه فى النفس البشرية ، و أصالة تعبيره عن حقائق تلك النفس ، بحيث لا يمكن أن ترد مسرحياته إلى مجرد أحداث

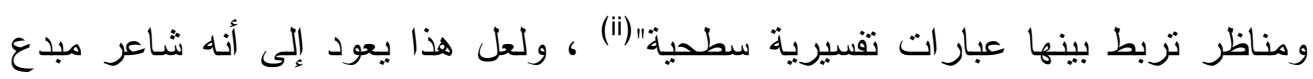

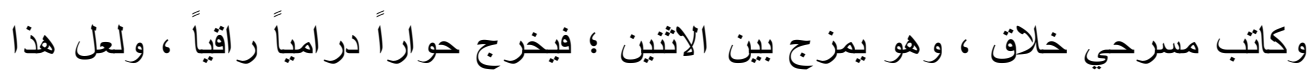

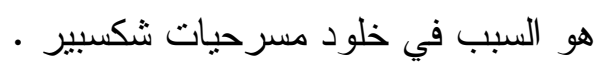

وفى مسرحية تاجر البندقية نجد أن شكسبير "صاغ أحداثها في ألفاظ غاية فى الروعة ، التي وإن أيقظت المشاعر و الأحاسيس ، إلا أنها توقف التفكير وتثنل العقل بحيث يتهبيل القيم التي تعرضها المسرحية دون إمعان فكر"(iii) ، فقد استخدم شكسبير النظم الشعري

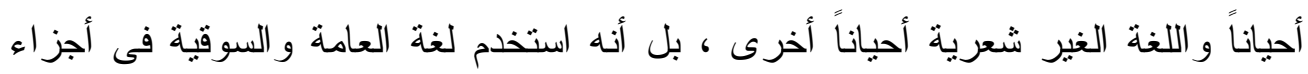
معينة من هذه المسرحية ، وهذا واضح فى حوار جر اتيانو الذى تلفظ بألفاظ سوقية وبذيئة أحياناً ، وهذا أمر لا بأس به طالما يعبر عن ثقافة الثخصية الدرامية ولئ وعن بيئتها - دون

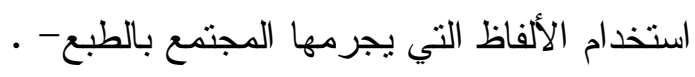
ويستخدم شكسبير النثر والثعر معا فى مسرحه وينتقل بينهما حسب مقتضيات الدر اما ، وقد يظن البعض أن القاعدة هى استخدام الثعر و أن النتر فى مسرحه ضئئيل هزيل ولئل ، ولكن

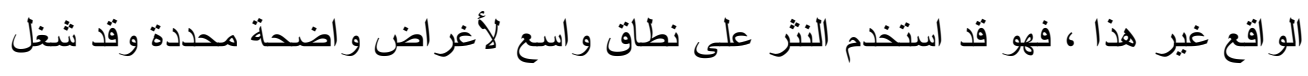

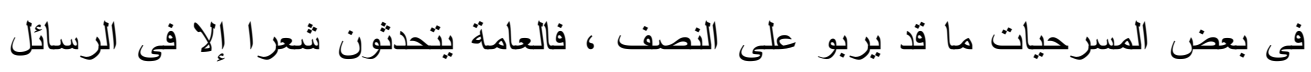

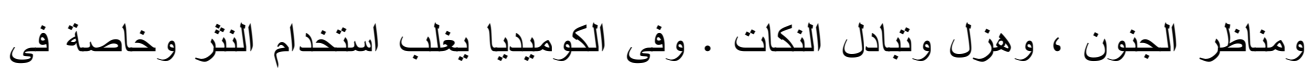

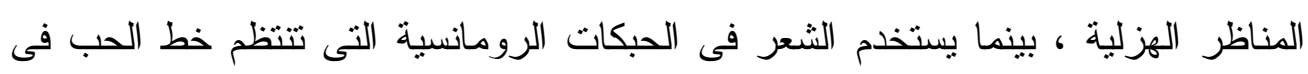
(الكو ميديا")

\section{مشكلة الار اسة}

لما كان الأدب - بوجه عام - هو سجل مشاعر الأمة وأر ائها ، ويستطيع أن ينقل

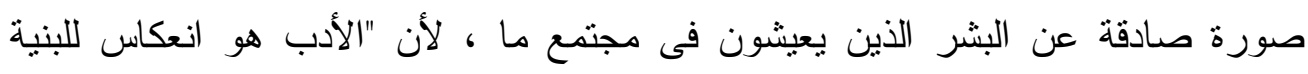




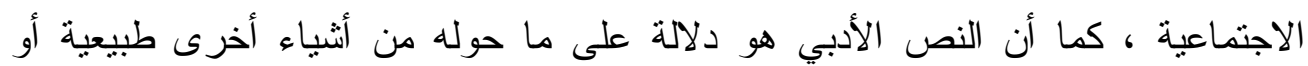

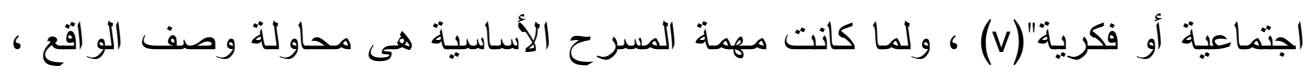

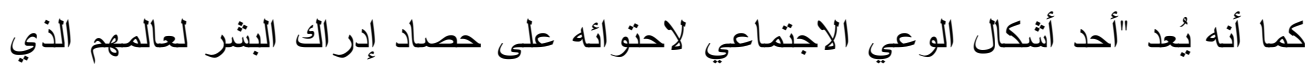

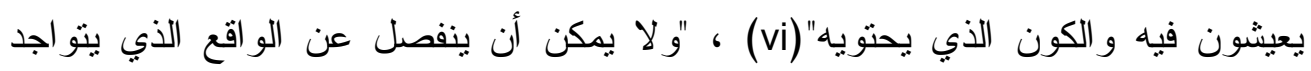

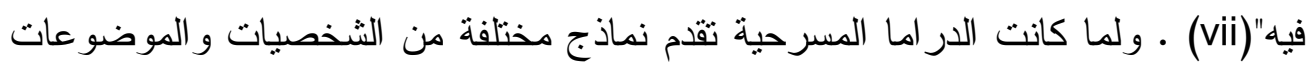

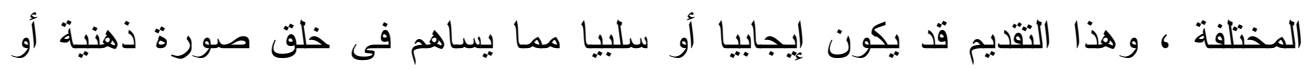

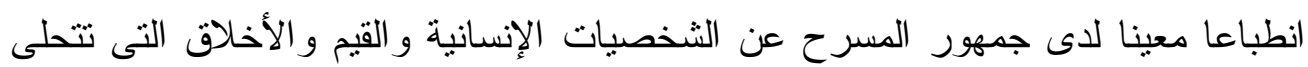

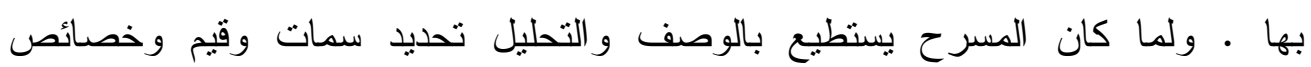

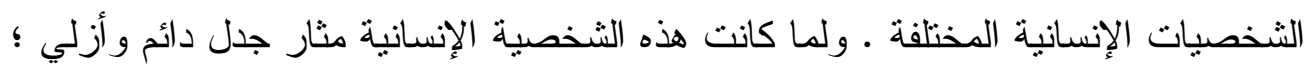

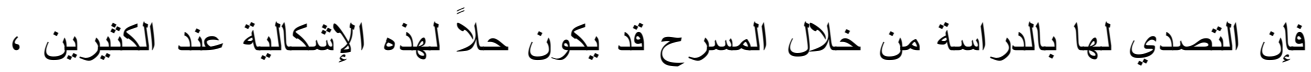

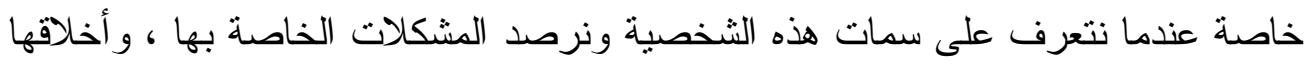
وقيمها المختلفة .

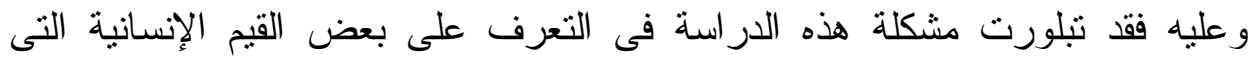
تتاولها وليم شكسبير فى مسرحه ، وذللك من خلال تحليل المضمون لمسرحيته "تاجر

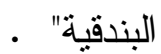

\section{تساؤلات الاراسة :}

ا - ما أهم القيم و المبادئ التي طرحها و أكدَّ عليها شكسبير فى مسرحيته "تاجر البندقية.

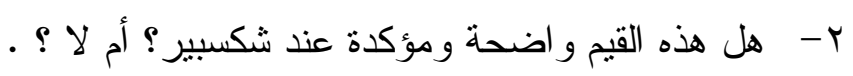
r- - هل هذه القيم هامة في حياتتا؟ أهمية الار (سية :

ترجع أهمية هذه الدراسة إلى أنها تتناول مجموعة من القيم الأخلاقية التى نحتاج إلى

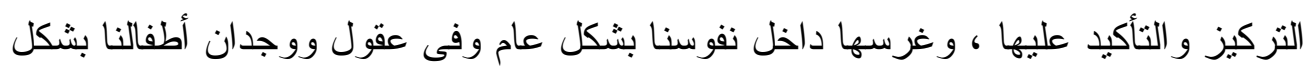
خاص ، لما لها من أهمية قصوى فى تربية إنسان سوى وصالح لنفسه ولمجتمعه.

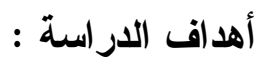

1- الكثف عن القيم الأخلاقية التي تتضدنها النص المسرحي "تاجر البندقية". r- التعرف على قوة ووضوح وتأكيد شكسبير على القيم التي تتاولها في نصه المسرحي

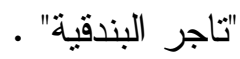


يعد البحث من البحوث الوصفية فى تحليل المضمون ـ حيث يستهدف الباحث من

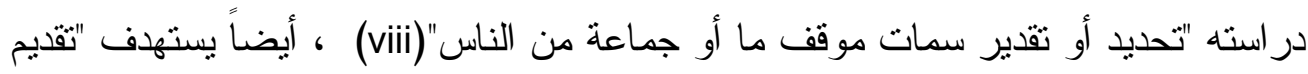

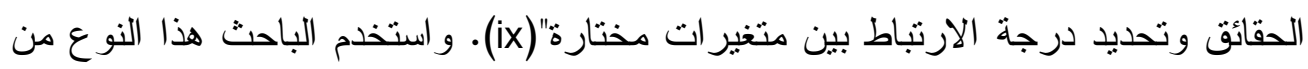
مناهج البحث لكي يصف القيم التى تتضمنها مسرحية "تاجر البندقية" . أداة تحليل المضمون ( Content Analysis):

تحليل المضمون: هو "أسلوب للبحث العلمي يسعى إلى وصف المحتوى"(x) ، "ويقدم

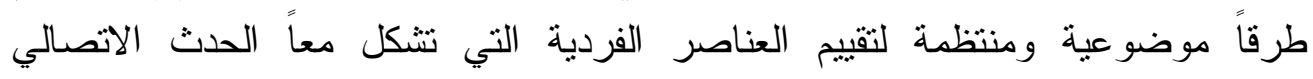

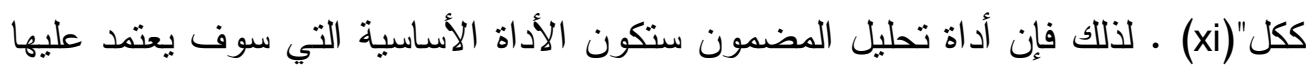

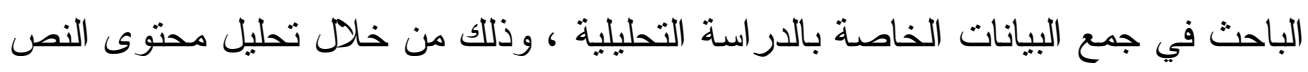

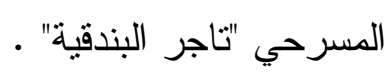

مجتمع الار اسة:

مجتمع الدراسة هو مسرحيات وليم شكسبير التى تحتوى على بعض القيم الأخلاقية

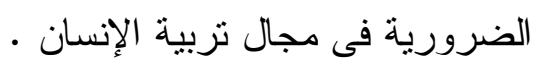

طريقة اختيار العينة : مبن

قر أ الباحث العديد من النصوص المسرحية لثكسبير ، وذلك للوقوف عند النصوص

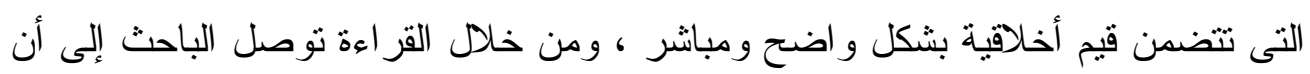

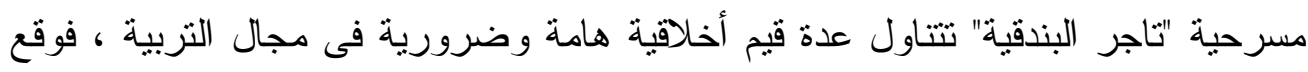
اختياره عليها لدر استها. الار اسات السابقة

- ار اسة مديحة عامر: قيم فنية وجمالية فى شعر صلاح عبد الصبور (xii).

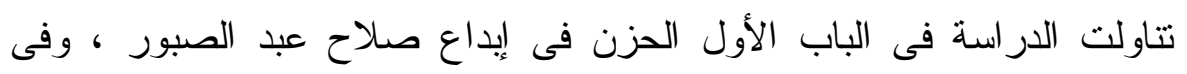

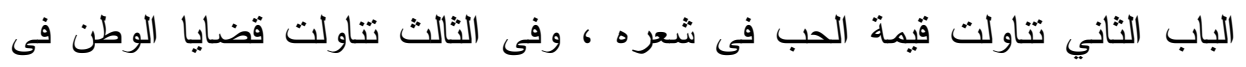

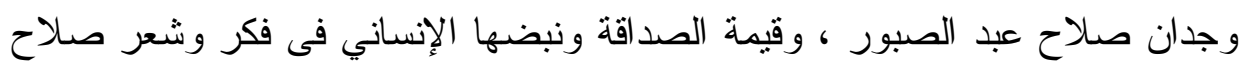

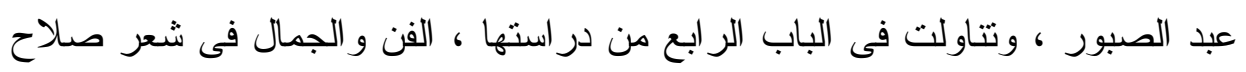
عبد الصبور 


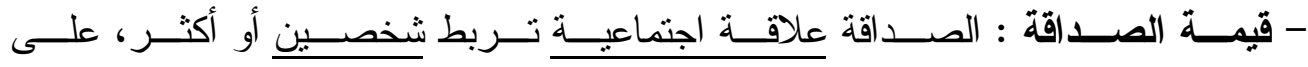

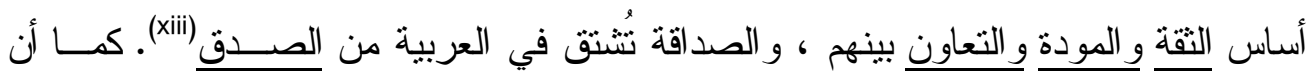

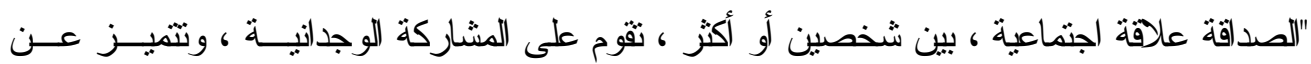

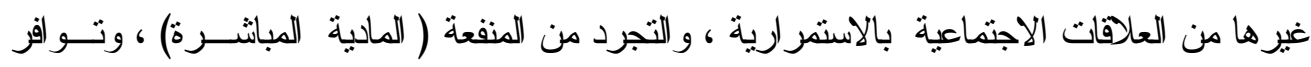

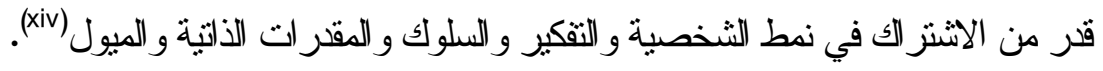

- قيمة الحب : الحبّ هو رابطة روحيّة ، و إحساس نفسي ، وشعور وجداني يعـيش فـي

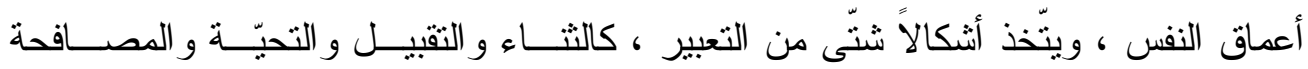

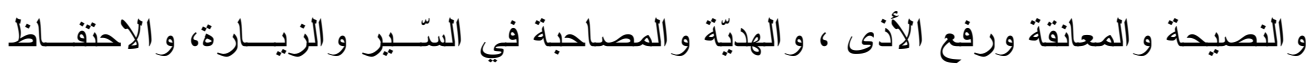

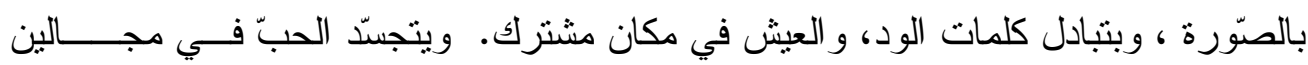

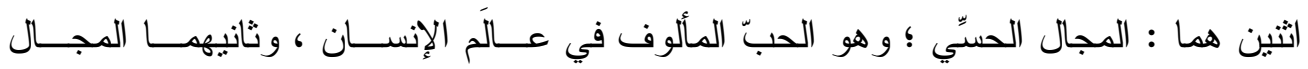

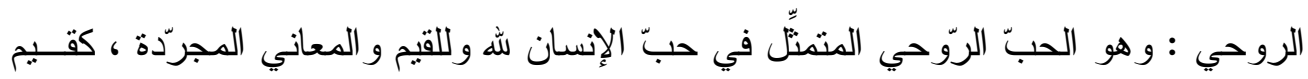
الحق و العدل (xv). (الروحي

- قيمة الوفاء : تتمتل في التفاني من أجل قضية ما أو شيء ما ، وهو خصلة اجتماعيــة ،

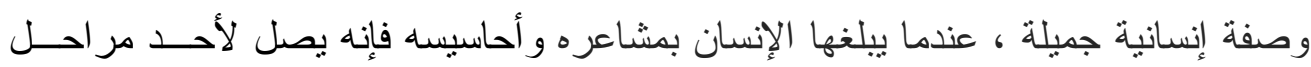

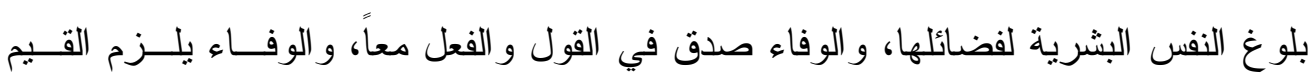

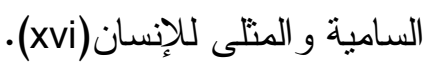
قيمة الرحمة: هى ليست عاطفة عارضة أو شفقة وقتية مرتبطة بموقف معين ، و إنما هـى

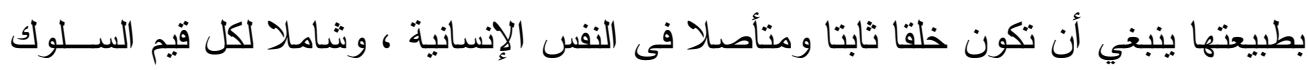
الفاضل فى التعامل مع البشر ومع كل الكائنات الأخرى فى هذا الوجود (xvii) .

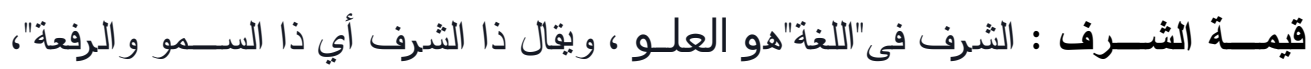

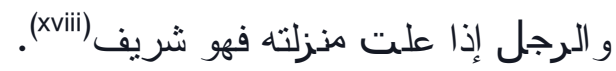

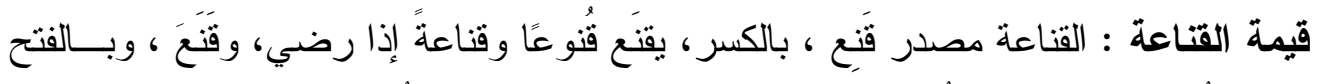

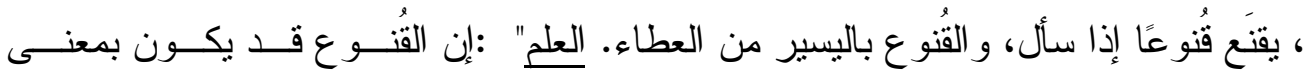

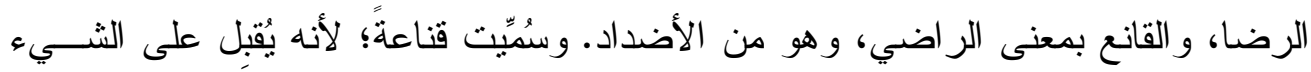

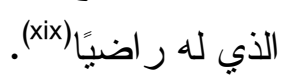


قيم فنية وجمالية فى مسرحية "تاجر البندقية" .. تأليف: وليم شكسبير

وليم شكسبير

"الحقائق الواضحة و الصحيحة عن حياته الثخصية ليست بالوضوح الكافي ، لأن

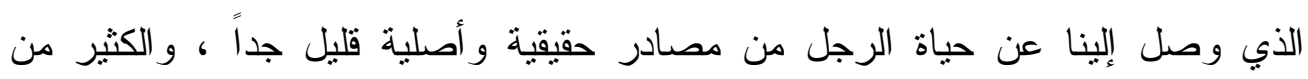
الحقائق المتاحة و الموجودة بين أيدينا عن حياته اعتمدت أغلبها على تخمينات و استتناجات من أعماله" (xx) (x) و"لد "وليم شكسبير فى بr أبريل من عام ع أب ام لأبوين ثريين - إلى حد ما - حيث

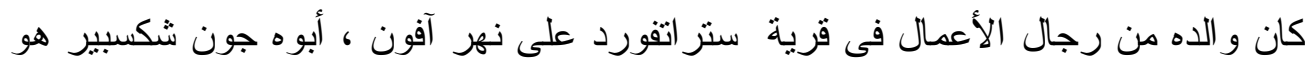

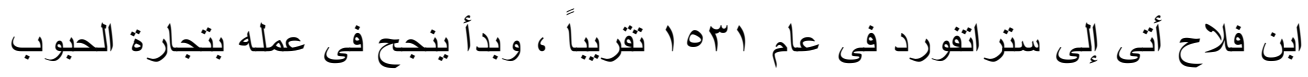

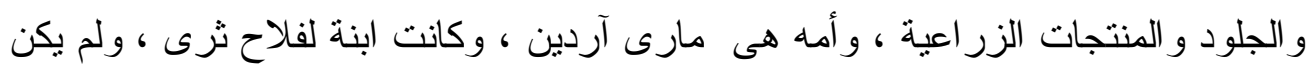

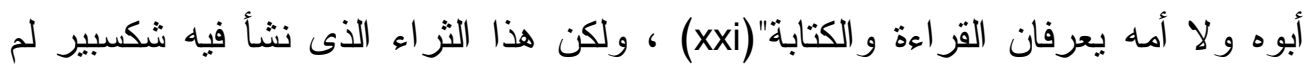

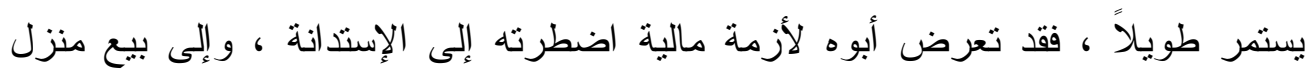

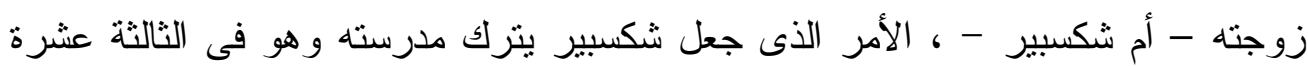

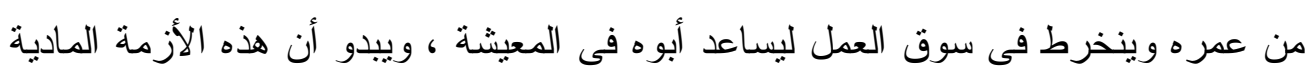

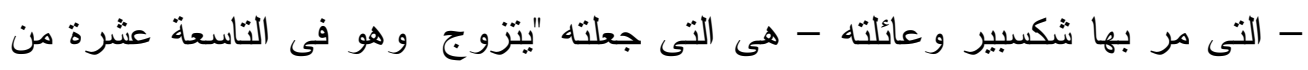

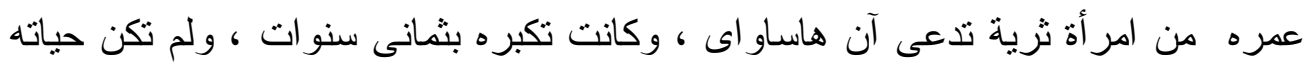

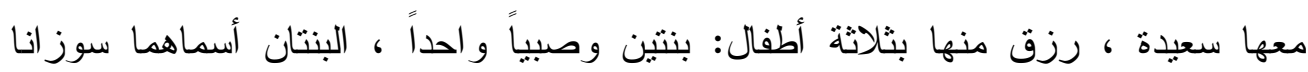

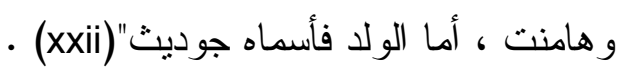

سافر شكسبير إلى لندن عام 1010 بعد أن شعر أن المعيشة فى ستر اتفورد أصبحت

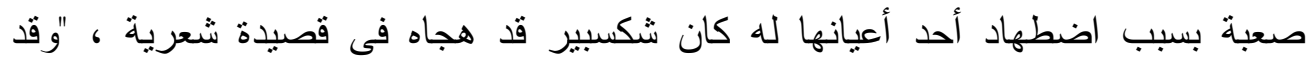

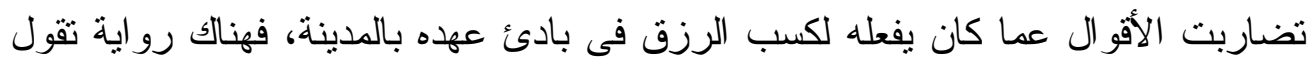

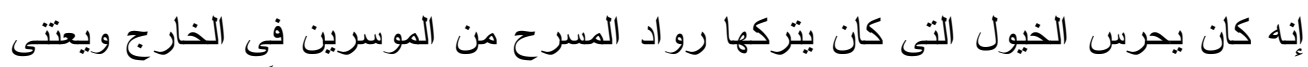

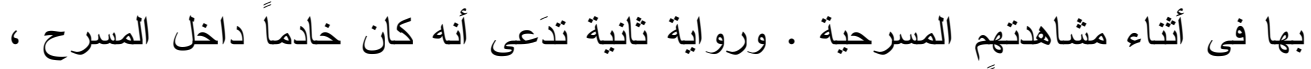

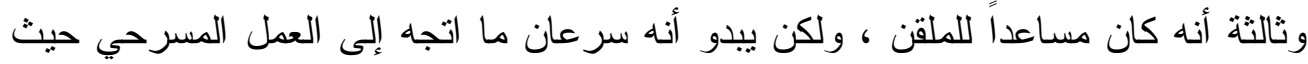

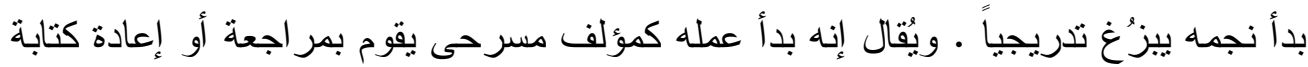
بعض المسرحيات التى كانت الفرقة تكلفه بها و التى كان لها لها الحق بمر اجعتها بعد شر ائها

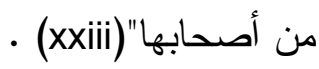


على أية حال فإن شكسبير قد ذاع صيته كممثل وكمؤلف منذ عام ب09 ام ، و أصبح من الأثرياء بعد سنوات قليلة من شهرته هذه لدرجة أنه اثشترى أغلى منزل فى بلدئه فئه الأصلية

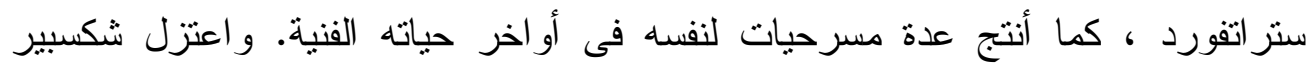
المسرح عام 1711 بسبب مرضه وبسبب عثقه لبلدته ستر اتفورد التى بدأ يقضى معظم

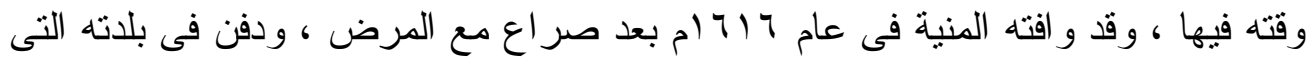

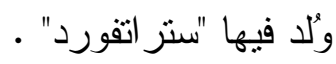

إن عظمة شكسبير"تتجلى فى الطريقة التى يحبك بها أطر اف القصة لتصبح مسرحية فنية متكاملة ، وفى الطريقة التى يصور فيها الثخصيات المتعددة ويطور ها بحيث تصبح إنسانية و اقعية ، وفى الثعر العظيم الذى تفوق فيه عن جميع أقر انه من الثعر اء الإنجليز ومعظم الثعر اء الآخرين فى جميع أنحاء العالم ، كما أن سر عظمة شكسبير أيضاً هو

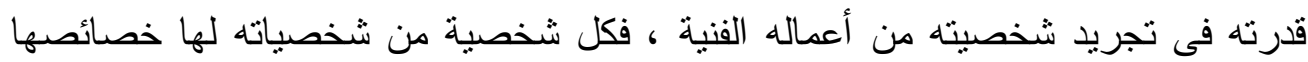

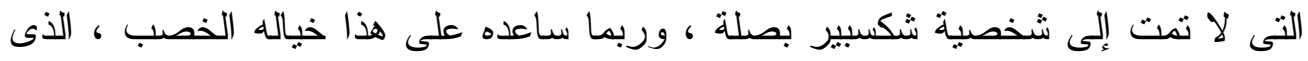

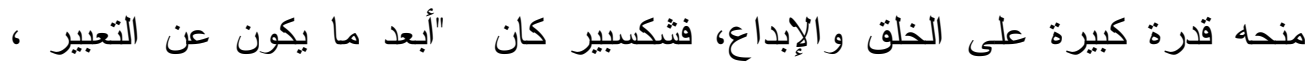

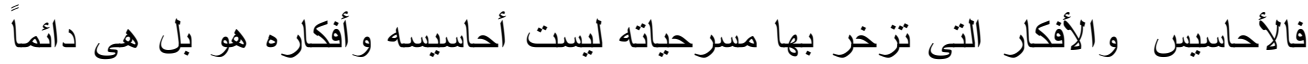
أحاسيس و أفكار شخوصه فى المو اقف الدر امبة المعينة التى يعيشونها"(xxiv) ـ

The Merechant of Venice "البناء الارامى لمسرحية " تاجر البندقية" تمناز مسرحيات شكسبير "بالدقة فى التصميم والبناء" (xxv) ، حيث أن "جميع

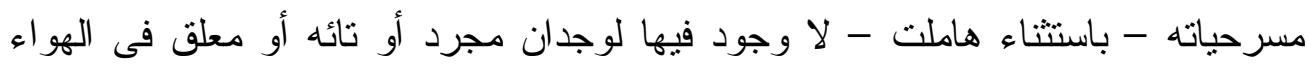
وبالمثل لا وجود فيها لفكرة مجردة أو صارخة أو خارجة عن مجرى المسرحية وتطور

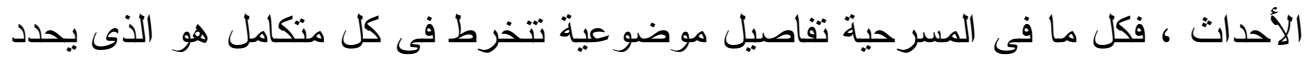

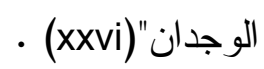

ومسرحية تاجر البندقية مسرحية كوميدية ، تتميز بتوازن البناء الدرامى "ثأنها شأن

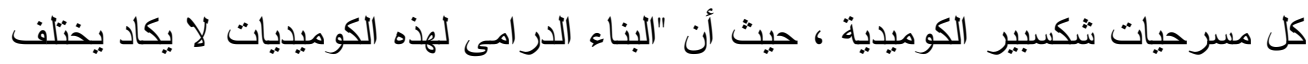

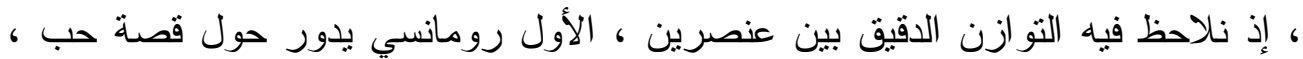

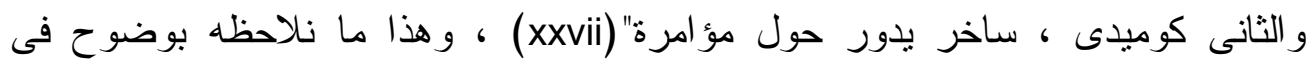

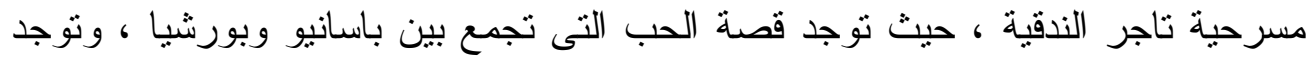


قصة المؤامرة النى دبر ها شيلوك لأنطونيو ، وتتداخل القصتان وتزتبطان ببعضهما البعض

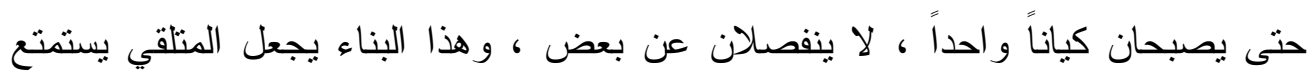
بقصة الحب ويضحك مع كوميديا الموقف فلا يشعر بالملل ـ وشيكسبير كتب المسرحيات

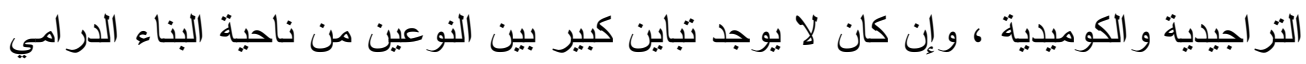

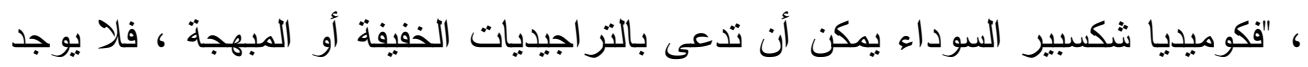
اختلاف بنيوي جذري بين كوميديات شكسبير وتر اجيدياته"(xxvii) ،

\section{عرض مختصر لأحداث مسرحية "تاجر البندقية"}

تبدأ أحداث المسرحية بأن يستتجد "باسانيو" بصديقه "أنطونيو" لكي يقرضه ثلاثة ألاف درهم لكى يسافر ويطلب الزواج من الفتاة الجميلة "بورشيا" ، ذات الحسب و النسب و المال

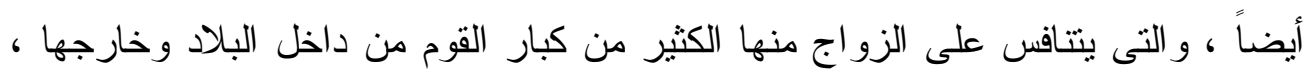

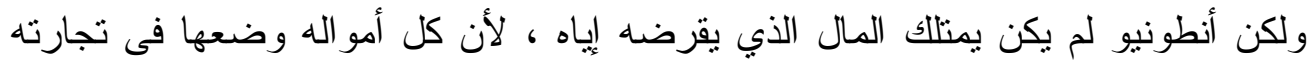

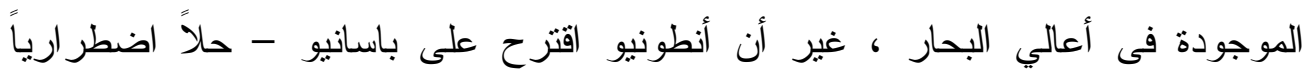

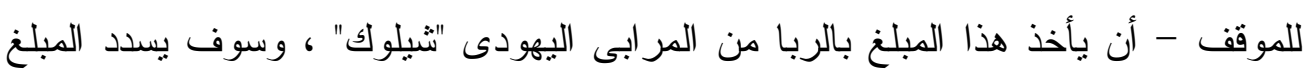

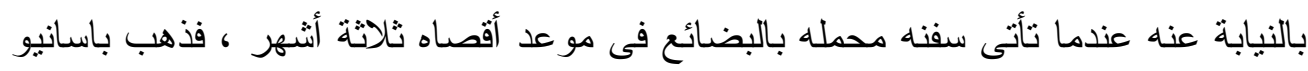

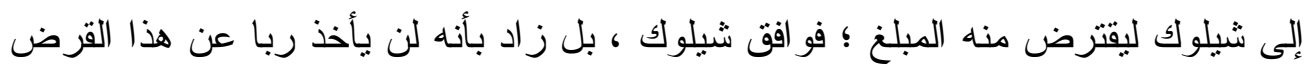

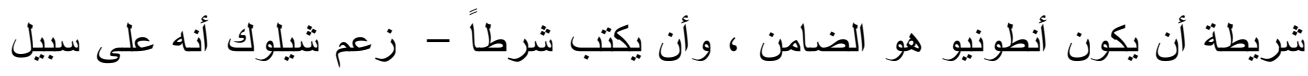

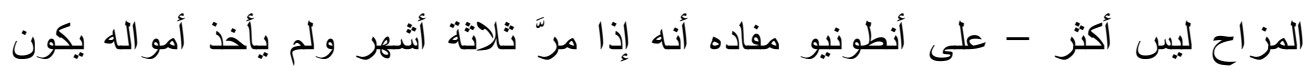

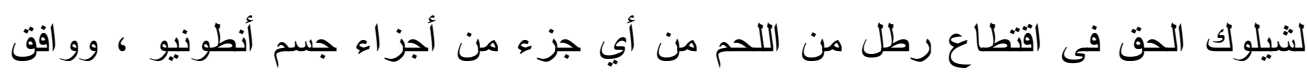

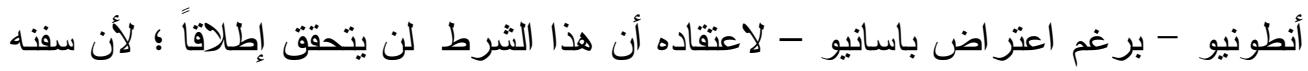

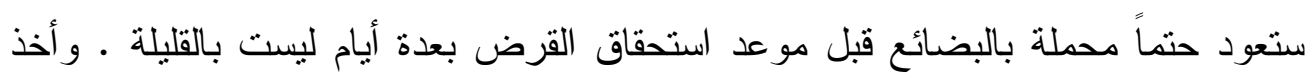

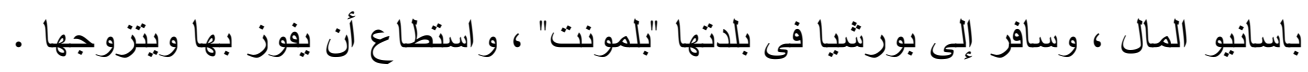
وكان لليهودي شيلوك ابنة تدعى "جيسيكا" ، لم تكن تحب الحياة مع و الدها ، وكانت

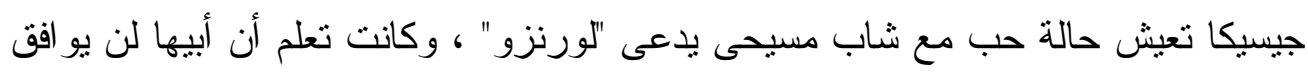

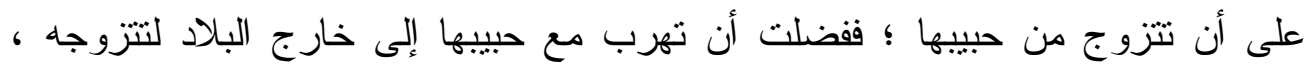

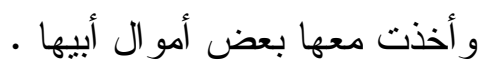


ومرت الثهور الثثلاثة ولم تأتى أي سفينة من سفن أنطونيو ، بل الأكثر من هذا أن تو اترت أنباء و انتشرت إنثاعات بأن سفن انطونيو قد غرقت فى أعماق البحار ؛ و أنه فقد

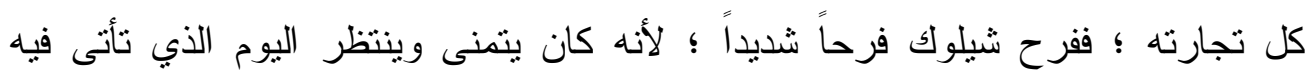

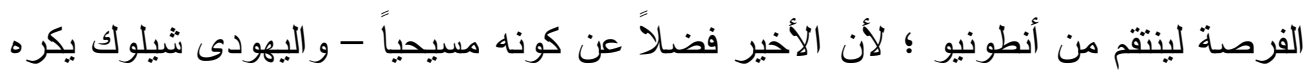

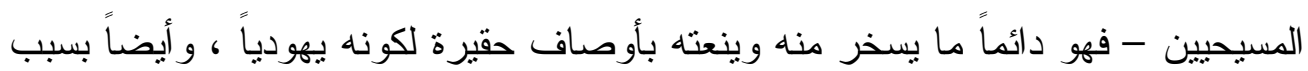

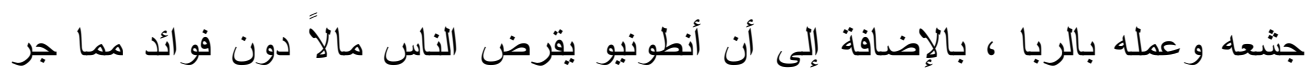
الخر اب على شيلوك كمراب لا يقرض المال إلا بفو ائد عالية.

ويذهب شيلوك إلى المحكة لكى يقاضى أنطونيو ، الذى لم بسنطع الوفاء بما كتبه على

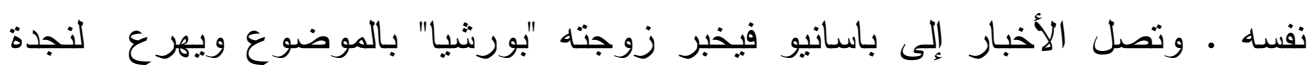

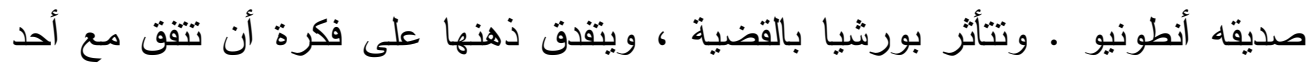

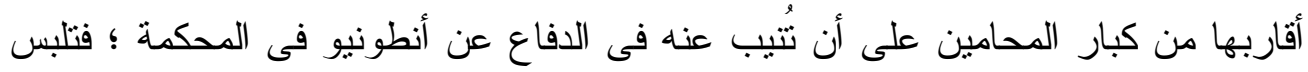

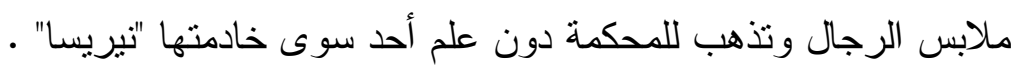
وتحاول بورشيا أن تستعطف شيلوك لكى يرحم أنطونيو ويقبل ما عرضه عليه باسانيو

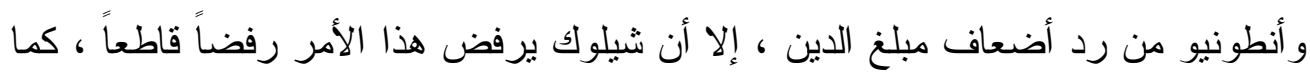

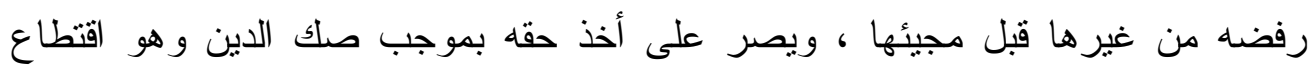

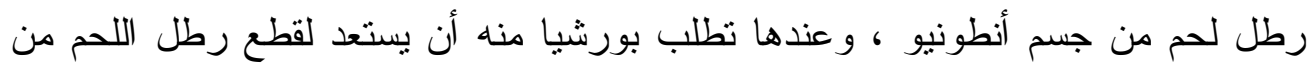

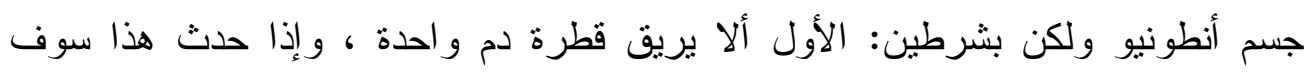

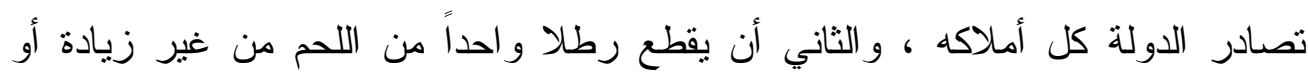

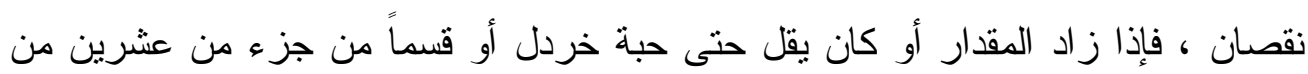
حبة خردل أو إن رجحت كفة الميزان مقدار الثعرة فلسوف يكون الموت مصبره وتصنادر الدولة كل أملاكه ، فيتر اجع شيلوك عن تمسكه بصك الدين ويحاول الحصول على رأس

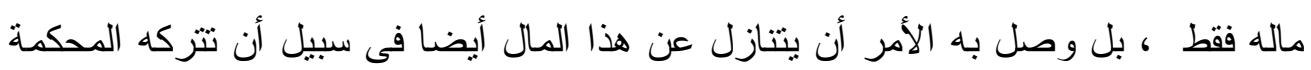

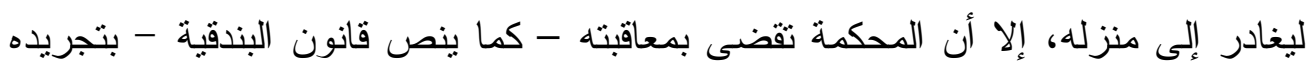

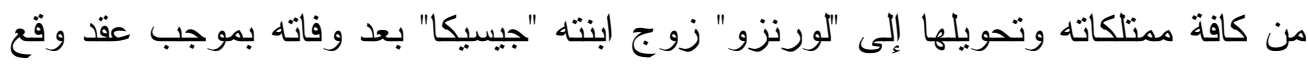

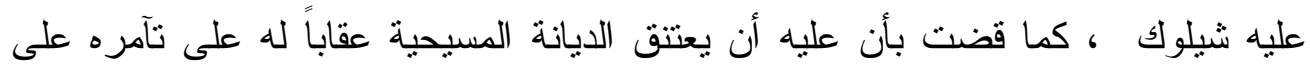
إزهاق روح مسيحى من سكان البندقية . 
تنتهي المسرحية بأن تعود سفن أنطونيو من أعالي البحار سالمة غانمة ، وأن الأقاويل

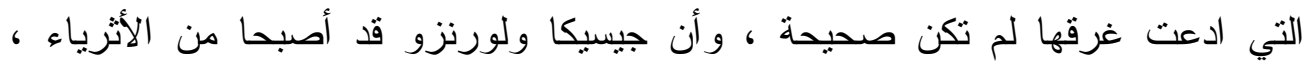
ويعرف باسانيو وجرانيانو وأنطونيو أن المحامى الذى أنقذ الأخير لم يكن رجل ولن - كما بدان

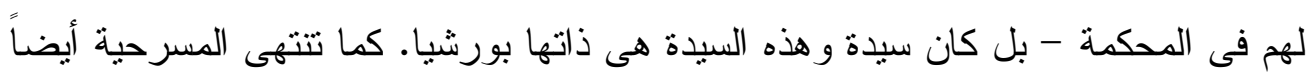

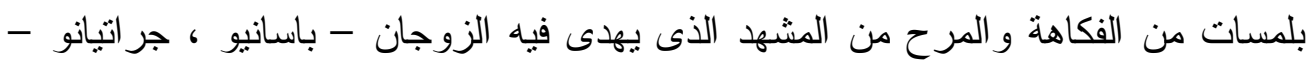

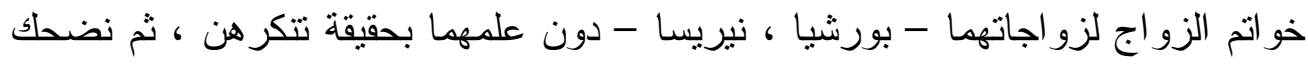

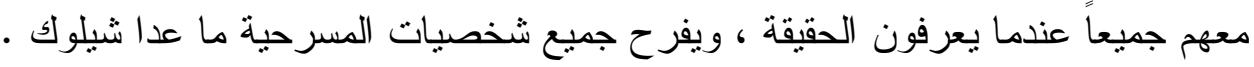

\section{الحزن في مسرحية تاجر البندقية}

فبر تاريخ الفنون و الآداب تختلف حكايات الألم ، وتتتوع مصادر المعاناة ولكنها تتجسد فى ذات الإنسان وعياً بالحقيقة ، ونضوجاً فى الفكر و العقل و التصور الات وات واستعلاء بالأحلام

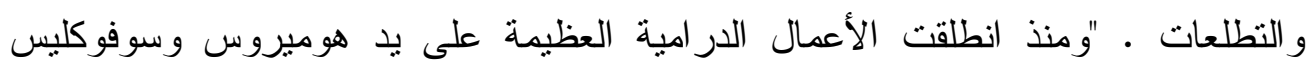

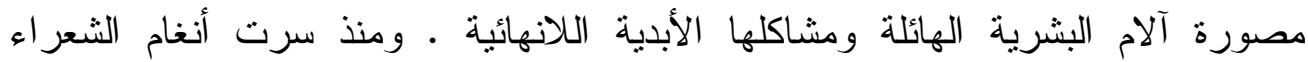
العظماء وانطلقت صيحات المفكرين و الفلاسفة عبر التاريخ احتجاجا على ما في الحياة من لهن

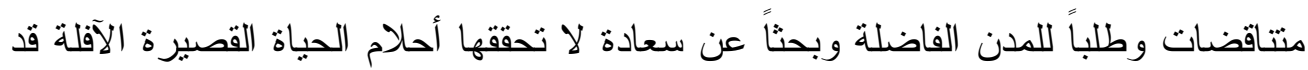
تتغير الأسباب وتختلف الغايات و المقاصد ولكن تبقى معاناة الألم نبعاً فياضاً للفن العبقري الفاء

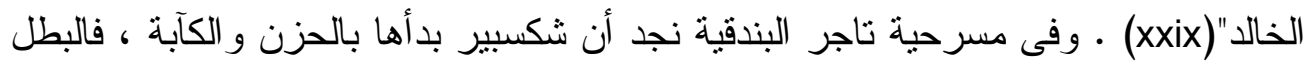

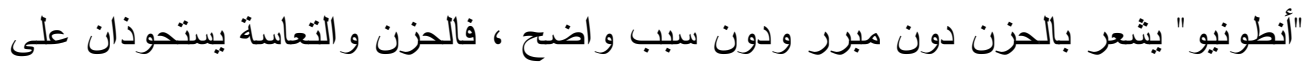

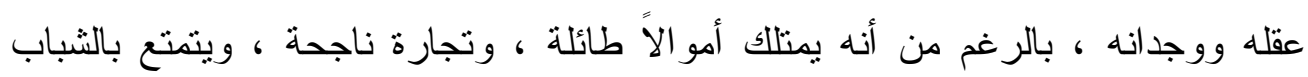
وبصحة جيدة.

أنطونيو : حقاً لا أعرف سِّ الحزن الر اسخخ فى نفسي! (...) .. لا أعـرف كيــ

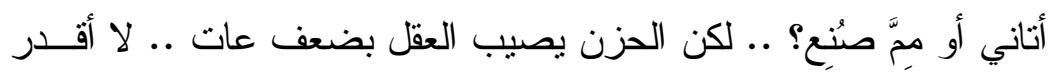

$$
\text { معه أن أعرف نفسي!(xxx). }
$$

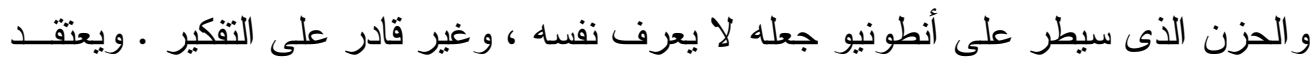

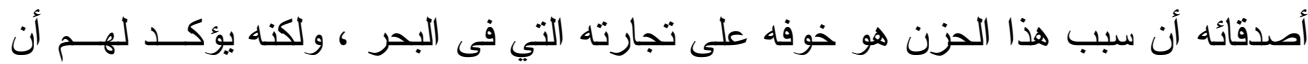

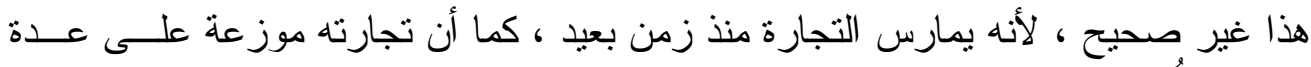

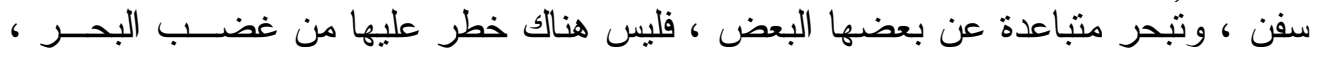




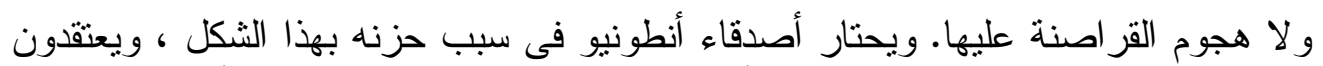
أنه وقع فى الحب ، ولكنه ينفى هذا تماماً ، ويرى أن الله قد خلقه ليكون حزيناً. ساليريو : (...) فالحزن لديه وليد الخوف على سفنه!

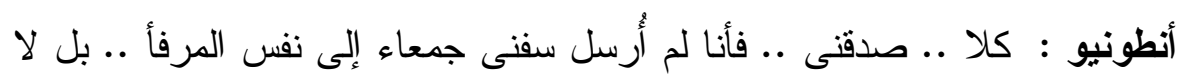
يستند ثرائي لتجارة عامي هذا وحده!

$$
\begin{aligned}
& \text { سولانيو : هو حزن الحب إذن! } \\
& \text { أنطونيو : أبداً أبدا . . }
\end{aligned}
$$

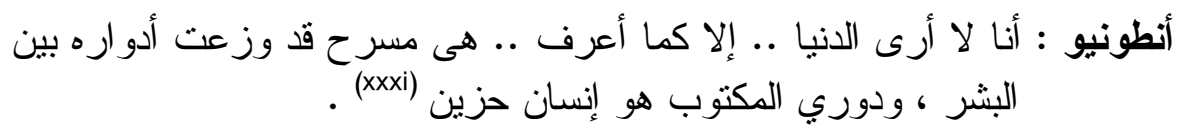

ولكن الباحث يرى أن الحزن لا يتفق مع شخصية منل شخصية أنطونيو منحه الله الجاه

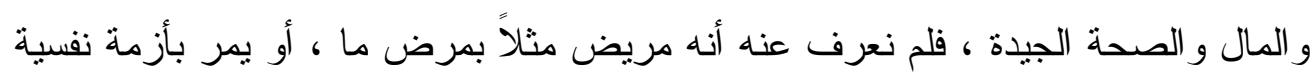

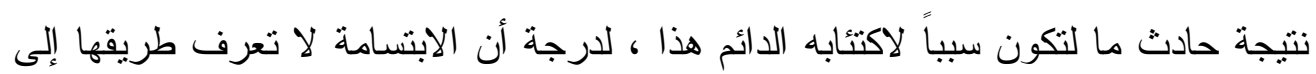

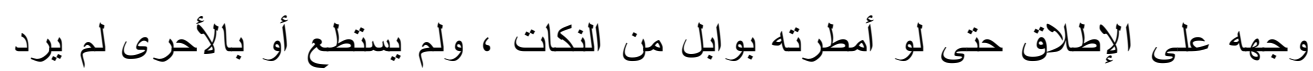
شكسبير بأن ييرر لنا هذا ، سوي أن أنطونيو لا يعرف سر سو حزنه الدائم.

وبالرغم من حزنه الدائم إلا أن أنطونيو طيب القلب وعطوف وكريم الخلق ، ويفعل الخير ، و هو ذو حس مرهف ؛ فدموعه تتساب لأي مشهد غير إنساني ، وهذا و اضح جئ جيداً

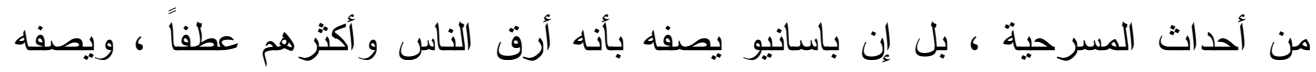

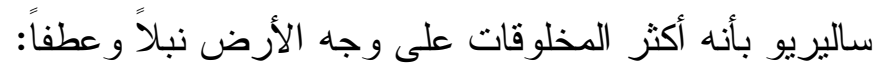

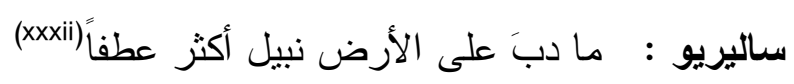

باسانيو : ... وأرق الناس و أكثر هم عطفاً ، لا يألو جهاً فى فعل الخير (xxiii)

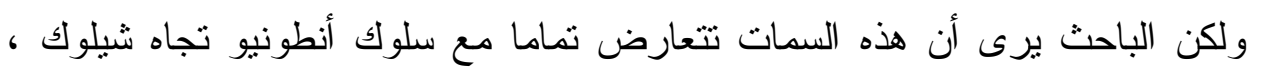

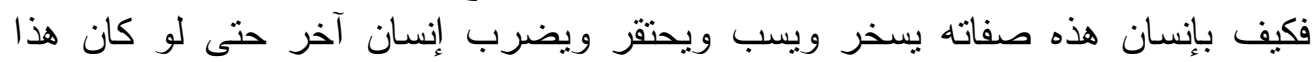

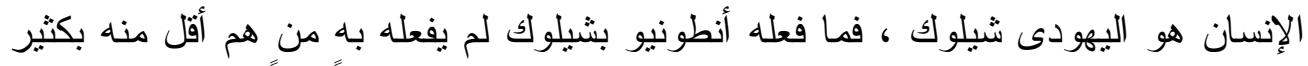

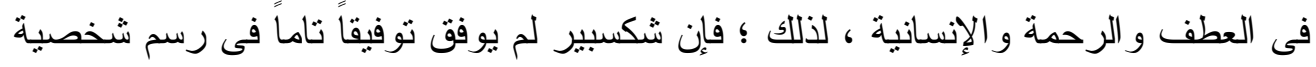




\section{"الصداقة" ونبضها الإساني و الفني في فكر ومسرح وليم شكسبير}

الصداقة فى علم النفس تؤدي وظيفتين أساسيتين : الأولى هي خفض مشاعر الوحدة ، ودعم المشاعر الإيجابية السارة من خلال خمس آليات رئيسية هي: المقارنة الاجتماعية

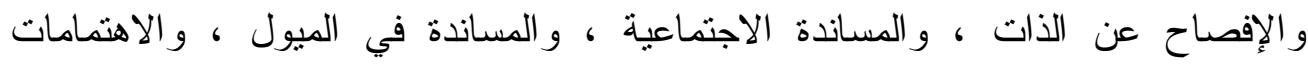

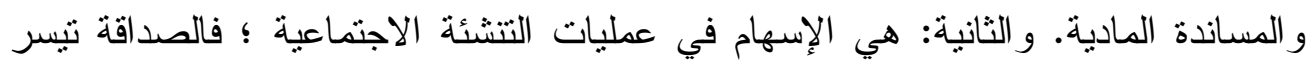

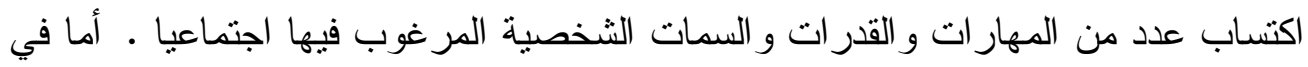
الفلسفة فقد عرفها أرسطو بأنها: عطف منبادل بين شخصين حيث يريد كل منهما الخير

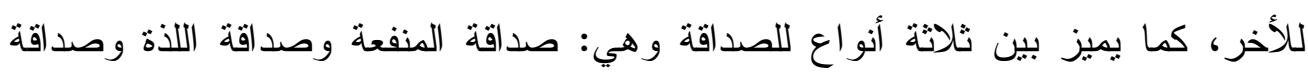

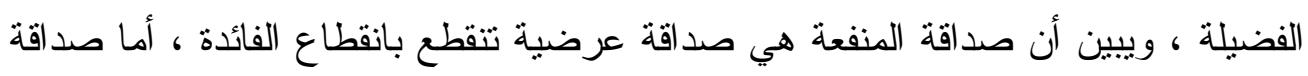
اللذة فتتنهى بعد إثباع اللذة أو تغير طبيعتها ، و أما صداقة الفضيلة فهي أفضل صدئ هداقة . "ولم تكن الصداقة قضية من القضايا الفكرية التي فجرها وكتب وتقرد بها شكسبير ،

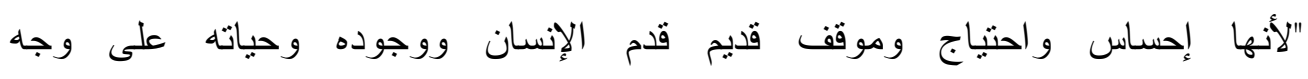

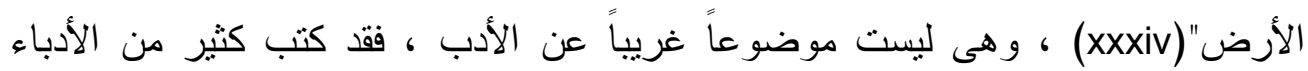

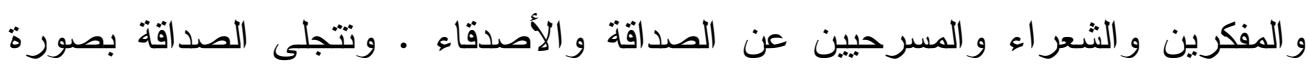

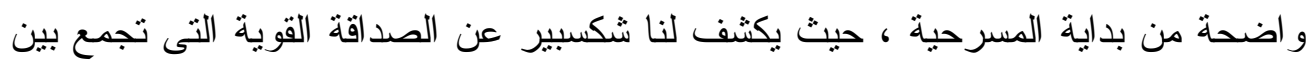

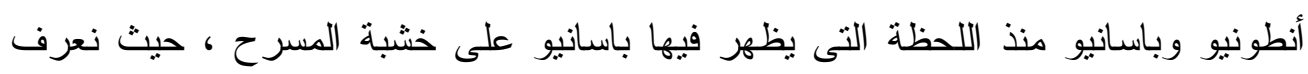

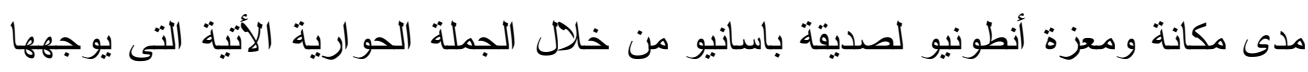
سو لانيو إلى أنطونيو لحظة قدوم باسانيو نحوهما:

سولانيو : ... (يدخل باسانيو ولورنزو وجر اتيانو) .. هذا باسـانيو قـادم !وهـــ

$$
\text { قريبك ذو القدر الأسمى! (xxxv) . }
$$

إن علاقة الصداقة بين أنطونيو وباسانيو من القوة و المتانة التى تجعل أنطونيو يضــع كــل إمكانياته المادية وكل ما يملك ، بل هو نفسه تحت أمر وطلب باسانيو : بانيو

أنطونيو : ... إن خز انتىَ وشخصى .. بل أقصى طاقاتى رهن إجابة حاجاتك (xxxvi). و أنطونيو يعاتب باسانيو لأن الآخير يحاول تبرير تأخره عن سداد مبلغ من المال كان

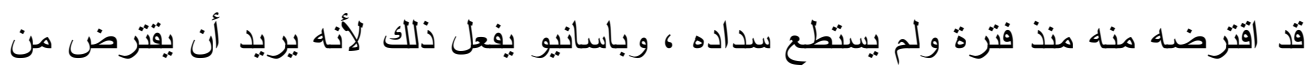


أنطونيو مبلغاً آخر حتى يستطيع السفر ويخطب يد الأميرة "بورشيا" ، التى وقع فى حبها . ونجد أن أنطونيو يغضبه خجل باسانيو وتردده فى طلب قرض آخر منه أكثر من تبديد

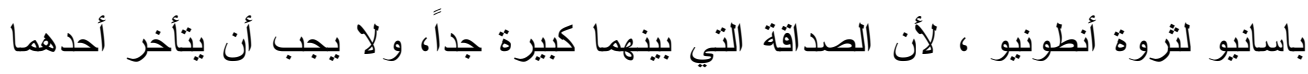

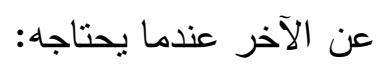

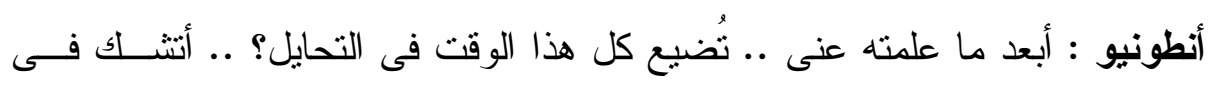

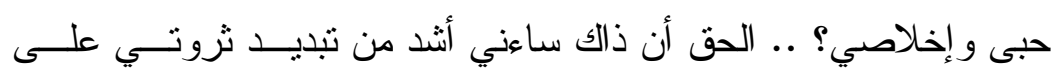

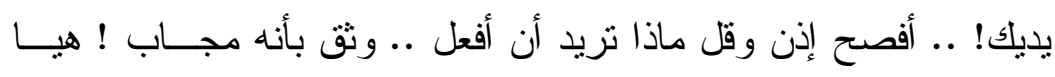

$$
\text { تكلم! (xxxvii) }
$$

ويطلب باسانيو مالاً كثير اً لكي يذهب إلى مدينة "بلمونت" ، ويخطب الأميرة "بورشيا"

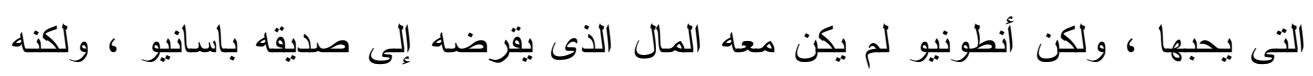

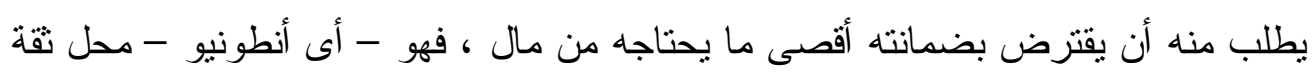
من جميع رجال البندقية .

أنطونيو : ... بضمانتى ستسنطيع الاقتر اض من رجال البندقية .. احصل على أقصى

$$
\text { الحدود الممكنة(xxxvii) }
$$

ويذهب باسانيو وأنطونيو إلى المرابى "ثنيلوك" ليقترضا منه ثلاثة ألاف دينار لمدة

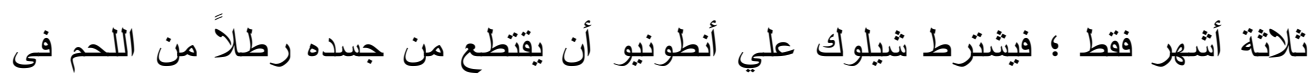

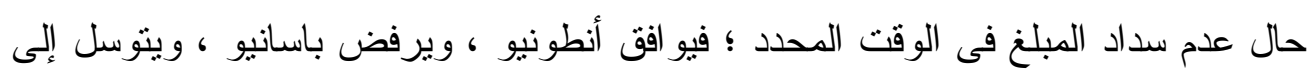

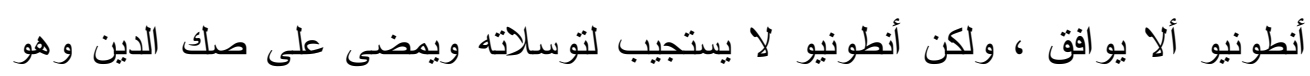

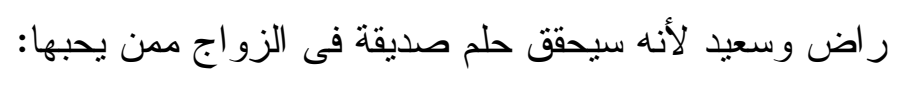
أنطونيو : أنا راض وسعيد .. ولسوف أُوقع هذا العقد باسانيو : لا أقبل أن تفعل هذا من أجلى ، و الأكرم أن أبقى فى ضائقتى (xxix). و عندما رحل باسانيو إلى "بلمونت" لبتقدم للزو اج من حبيبته "بورشيا" ، ودعه أنطونيو

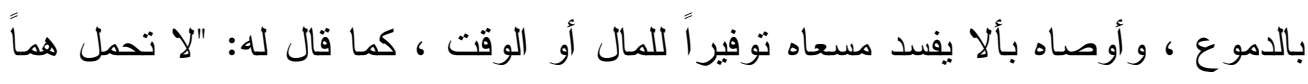

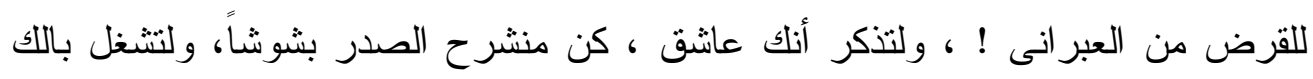

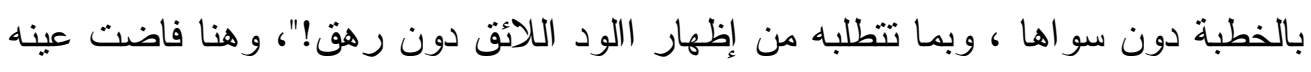




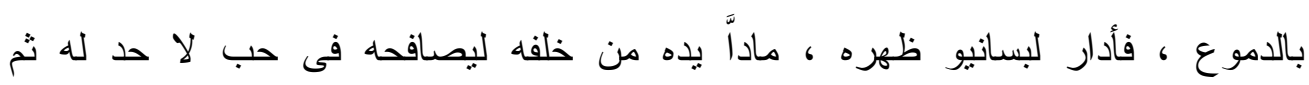

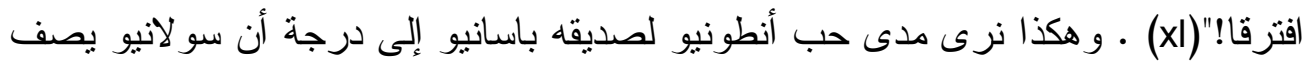
أهمية هذه الصداقة التى تجمع بين أنطونيو وباسانيو بأنها هى التى تمنح لأنطونيو لنى الحياة:

$$
\text { سولانيو : قُل إنه لو لم يكن صديقه ما اهتم بالدنيا ولا أحبها(xl) . }
$$

و وندما جاءت رسالة لباسانيو فحو اها أن صديقه أنطونيو فى أزمة تألم باسانيو كثيراً ،

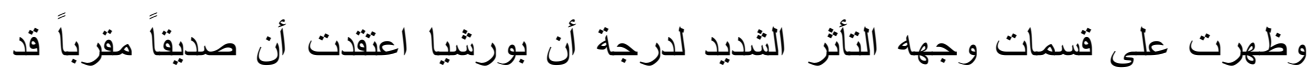
مات من شدة تأثز باسانيو أثناء قر اعته للرسالة ، و وعندما سألته عن فحوى الرسالة أجابها: إنها أسوأ رسالة فى التاريخ ، فهى تحمل أخبار سيئة عن صديقه أنطونيو الذى يعتبره أقرب أهل الأرض إلى قلبه وأرق الناس و أكثر هم عطفاً:

بورشيا : (تتأمل بسانيو أثناء قراعته الرسالة) .. لابد أن هذه الرسالة تحمل أنباء

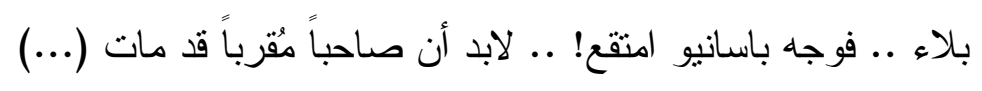

باسانيو : (...) لم تشهد الأور اق فى تاريخها أسو أ مما هو مكتوب هُنا!.

$$
(\ldots)
$$

بورشيا : أوَذ ذاك صديقلك المُقرب؟ .. صديقلك الذى يو اجه الخطر؟

باسانيو : بل أقرب أهل الأرض إلى قلبى ، وأرق الناس و أكثر هم عطفاً (xlii) وتحتوى الرسالة التى أرسلها أنطونيو إلى باسانيو معان عديدة لقيمة الصداقة ؛ فأنطونيو

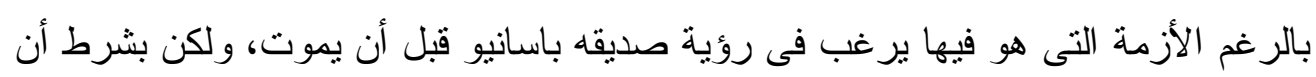
تسمح ظروفه بهذا ، ويرجوه ألا يُعدل عن رغبته فئ فئ خطبة بورشيها. كما أن أنطونيو يتمنى حضور صديقه باسانيو لحظة اقتطاع رطل اللحم من جســده حتـى

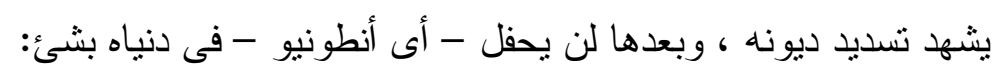
أنطونيو : ... إن جاء إلينا باسانيو حتى يشهد تسديد ديونه لن أحفل فى دنياى

$$
\text { بشى! (xliii) }
$$

ويصف لنا شكسبير بعضاً من سمات الصداقة الحقيقية ، حيث يقول على لسان بورشيا:

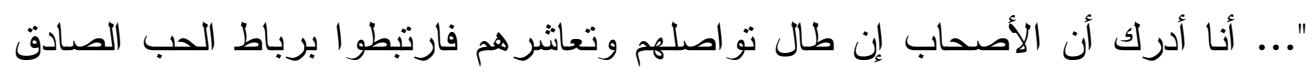


لابد لهم أن يشتركو ا فى بعض صفات الخَّق أو الخُلقِ بل فى نفس الروح! ، ولذا أتصور

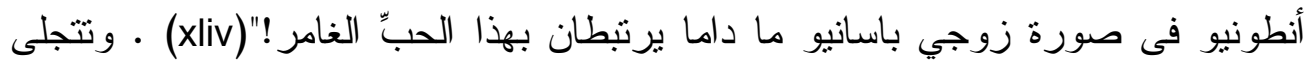

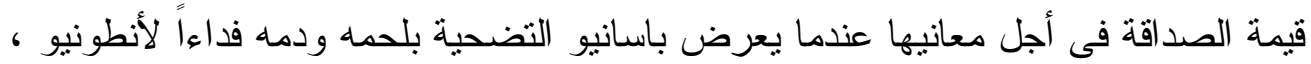

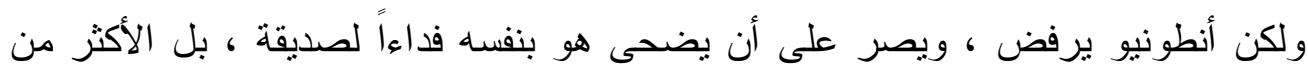

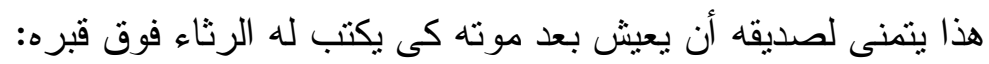

باسانيو: لن تُسَكَكَ من أجلى قطرة دم ، وليفز العبر انى بلحمى ودمى و عظامى!

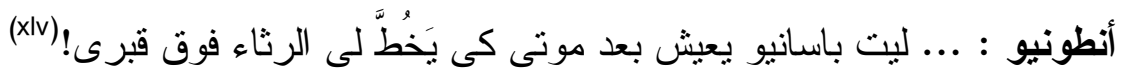

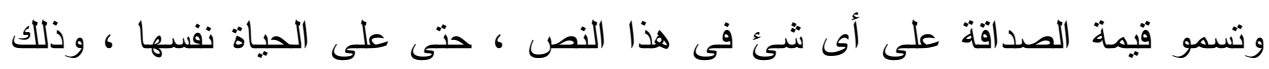

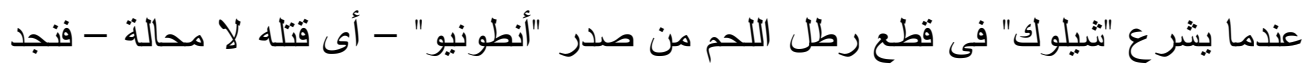

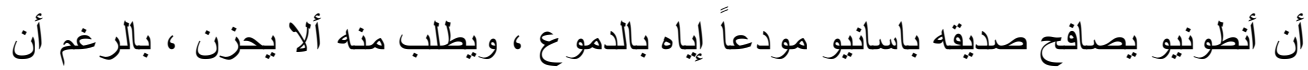
الأخير هو سبب بلاءه ، إلا أن حب الصديق لصديقه يفوق كل شئ في الوجود:

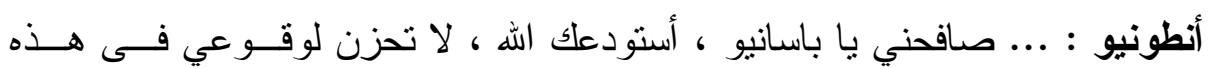

$$
\text { المحنة من أجلاكي(xlvi). }
$$

\section{قيمة "الحب" في مسرحية "تاجر البندقية"}

الحبّ حالة نفسـيّة و عاطفية تتبع من أعماق الإنسان لتمنحه السعادة و الهناء ، وربطه

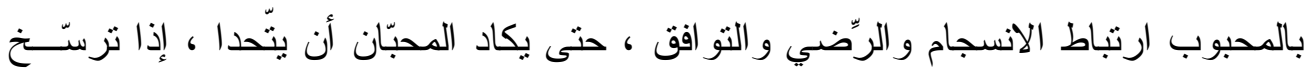

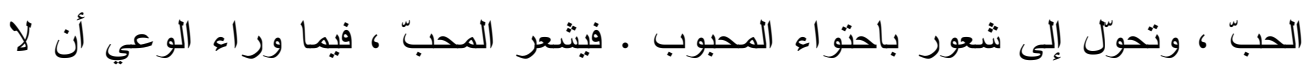
فرق بينه وبين حبييه ـ فهما حقيقة واحدة ، وذاتان مندمجتان في ذات النفس ـ ـ و لأهمية

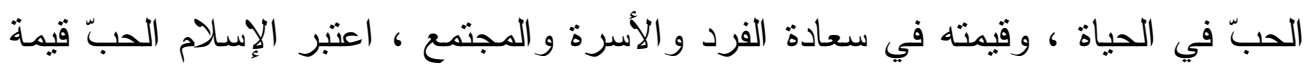

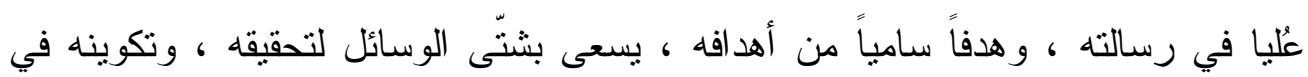

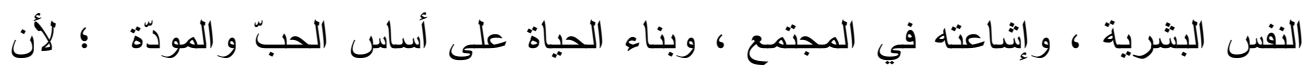

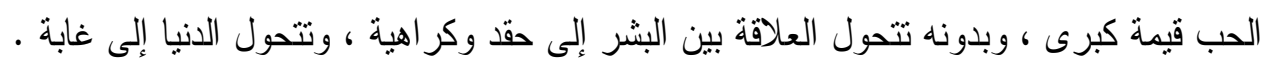

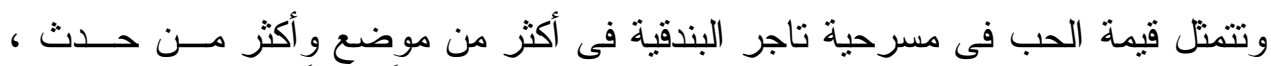

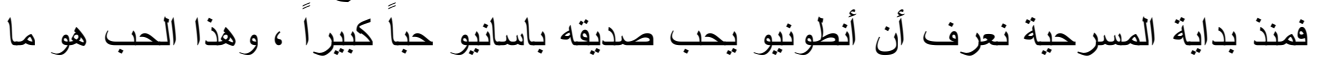

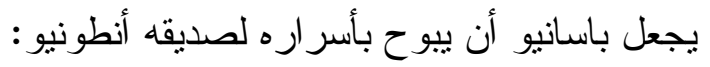

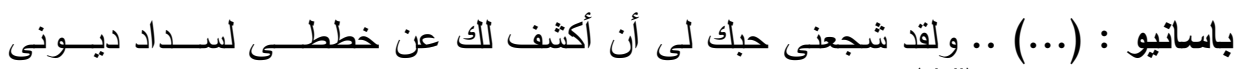
جمعاء!) 
كما نرى قيمة الحب فى علاقة الحب القوية التى تجمع بــين جســيكا - ابــن اليهــودى شيلوك - وبين الثاب المسيحى "لورنزو" ، تلك العلاقة التى تجعل جسيكا تتخلى عن دينهـ

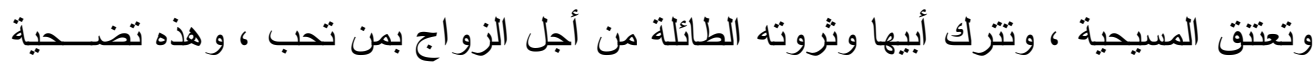

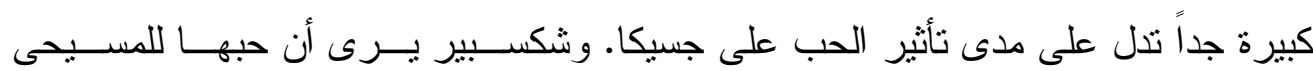

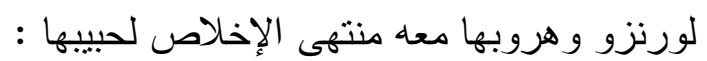

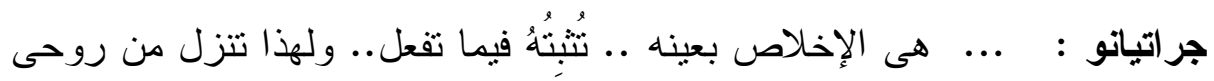

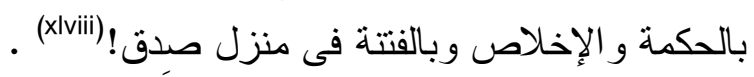

ويتفق الباحث مع شكسبير فى أن من حق جيسيكا أن تحب وأن تختار شريك حياتها

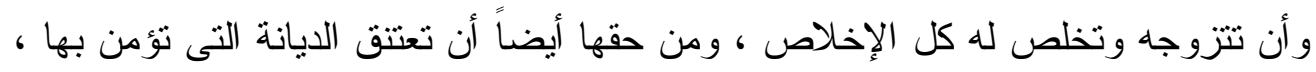
ولكن يختلف معه فى وصفها بالمخلصة ، حيث أن جيسيكا ليست هى الإخلاص بعينه -

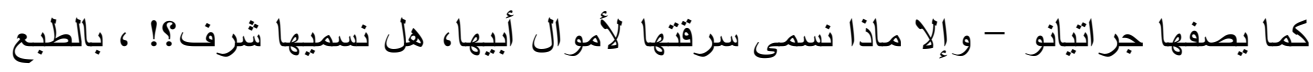

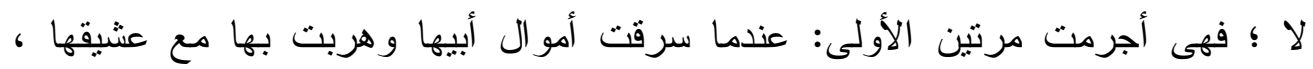

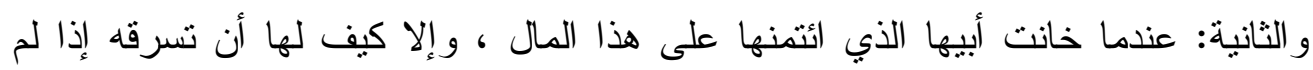

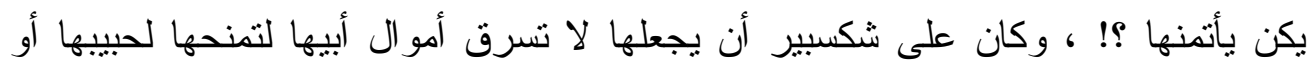

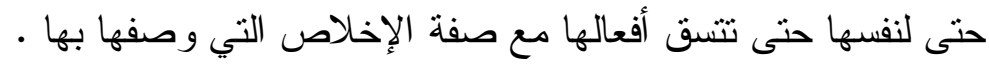
كما نرى الحب يجمع بين قلبى بورشيا وباسانيو ، فباسانيو اقترض أموالاً حتى يذهب

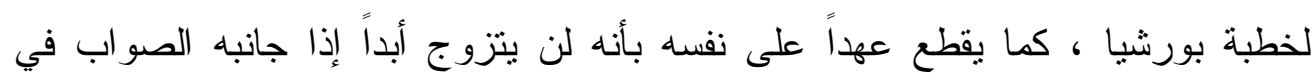

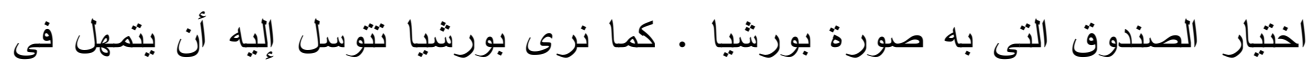

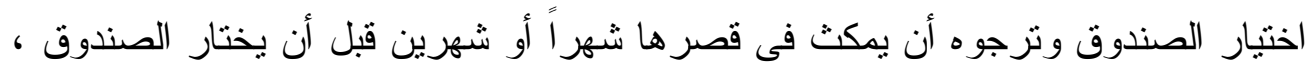

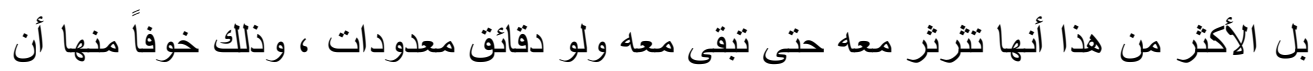
يخطأ فى اختيار الصندوق الصو اب فتقده إلى الأبد:

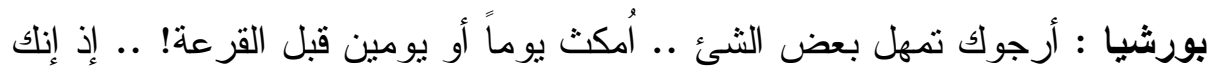

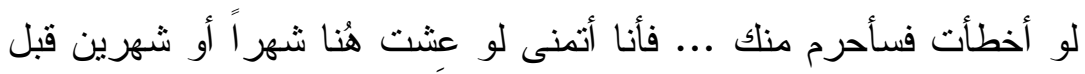
القرعة .. أتمنى لو علمتلك سِر القرعة حتى تختار الصندوق الصائب ...

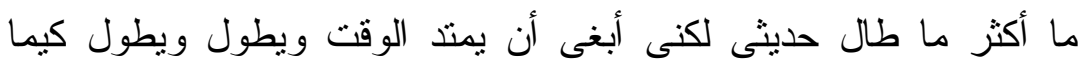

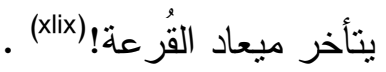


ويعرض لنا شكسبير ما للحب من قيمة كبيرة فى حياتتا ، فالحب يجعل البشرية تتسـامح

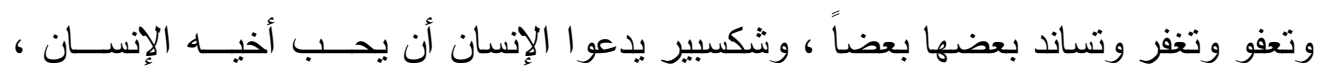

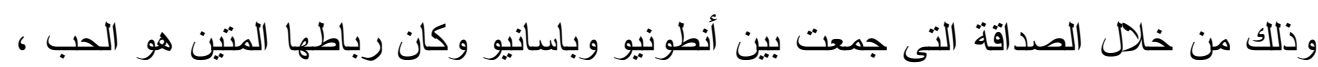

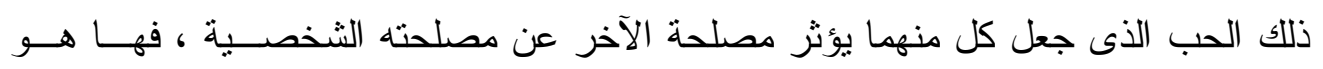
أنطونيو يُعرب لصديقه باسانيو - عندما أوشكت حياته على الانتهاء - عن مدى حُبه له: دئه أنطونيو : ... أبلغ زوجنك الغر اء تحياتي ، أخبر ها كيف قضى أنطونيو ، قُل كم

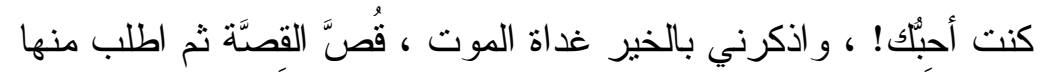

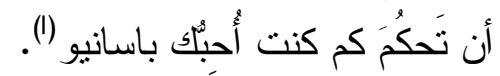

وكما أعرب أنطونيو لصديقه عن مدى حبه له ، أعرب كذلك باسانيو لصديقه عن مدى حبه له أيضاً:

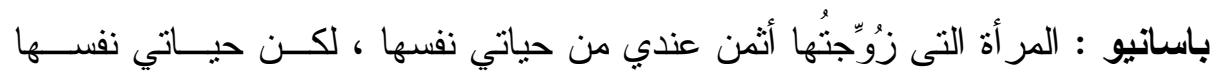

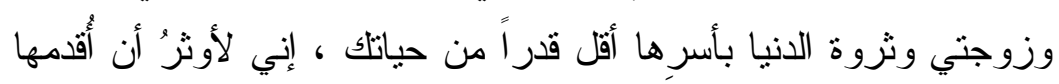

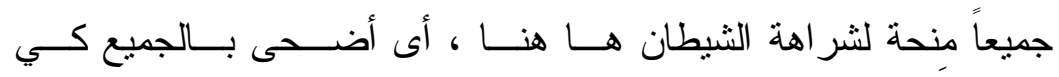

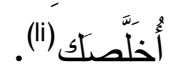

إن الحب عند شكسبير أسمى وأرقى وأثنن ما فى الوجود ، فالحب أكبر من كل الأموال

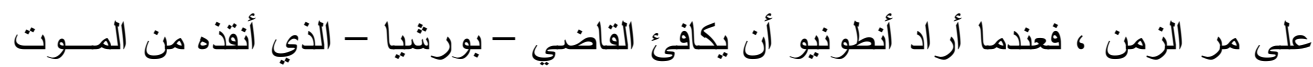

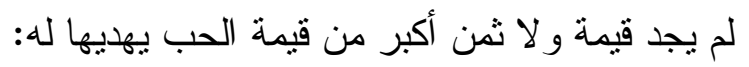
أنطونيو : ولسوف نظل ندين بدين الثكر ودين الحب له ديناً أكبر من كل الأمــوال

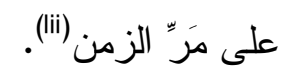

\section{قيمة "الوفاء" فى مسرحية تاجر البندقية}

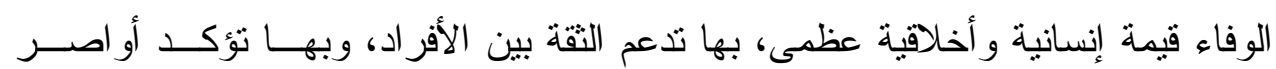

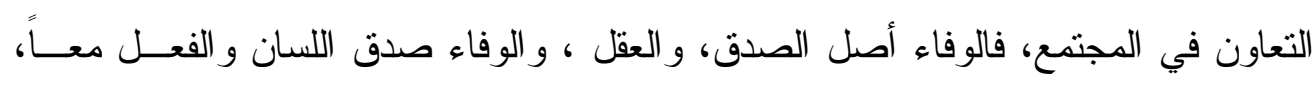

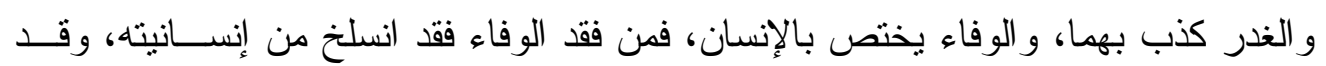

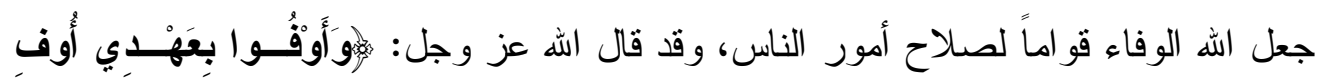

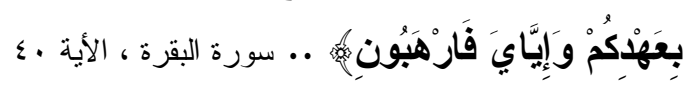




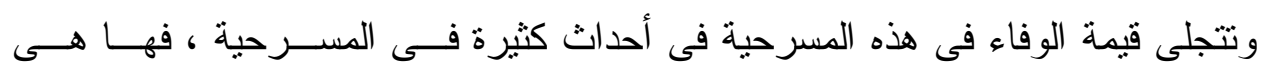

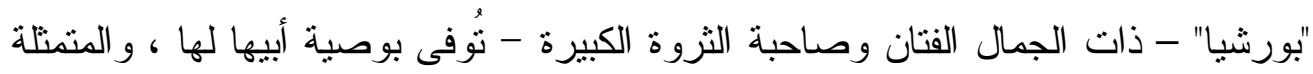

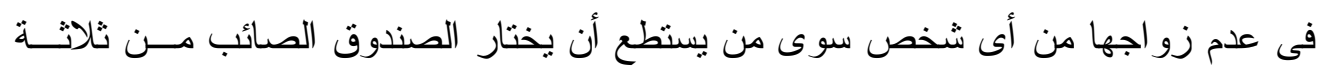

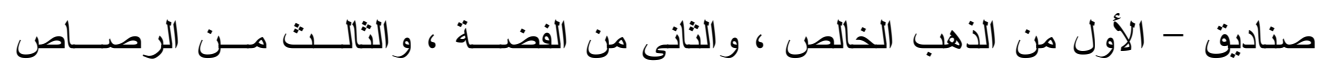

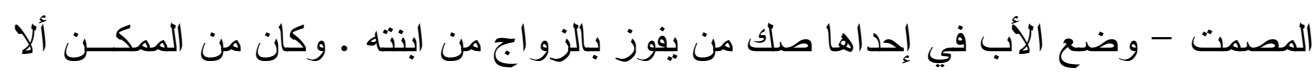

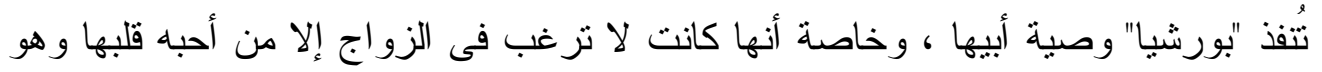

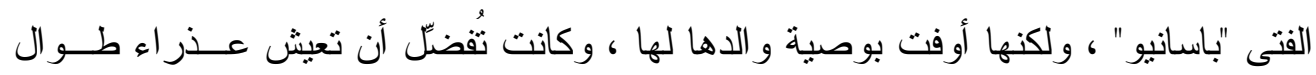

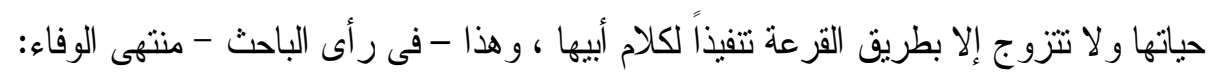
بورشيا : لو عشت إلى ألف سنة .. فلسوف أعود إلى ربى عذر اء كمــا جئـت و لا أتزوج أحداً منهم ، إلا بطريق القرعة تتفيذاً لكلام أبى!(iii) .

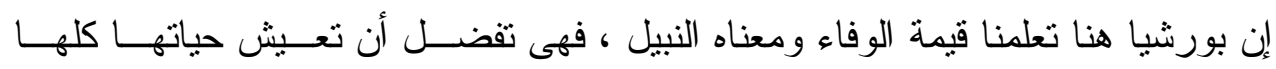

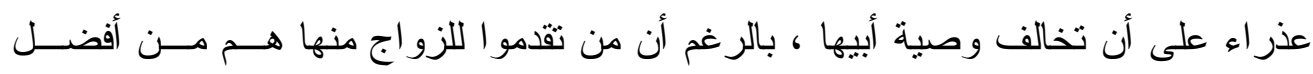

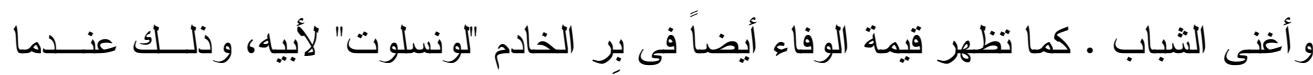

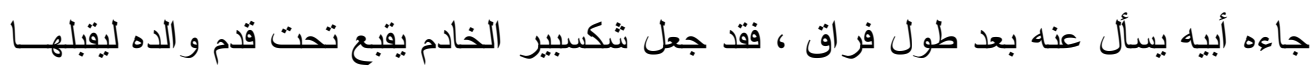

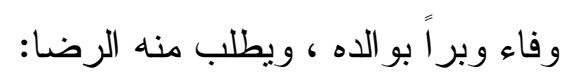

$$
\text { لونسلوت : ... (يركع أمام و الده) أرجو رضاك عنى (iv) . }
$$

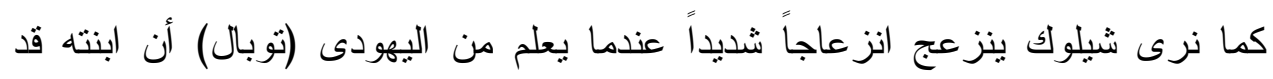

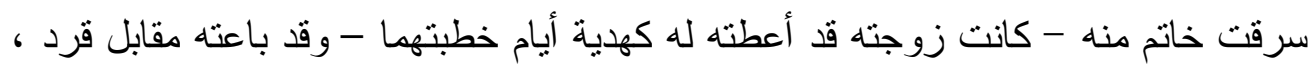

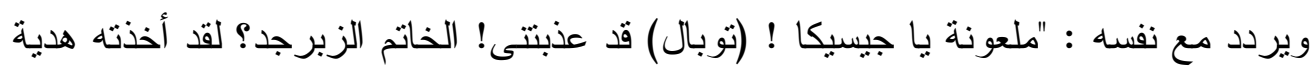

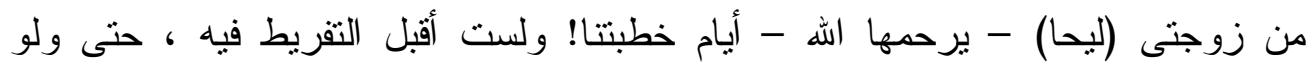

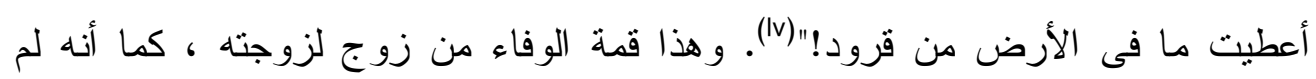

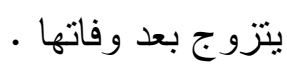
كما يتجلى الوفاء و اضحاً من رد فعل باسانيو عندما علم بالمشكلة التى وقع فيها صديقه

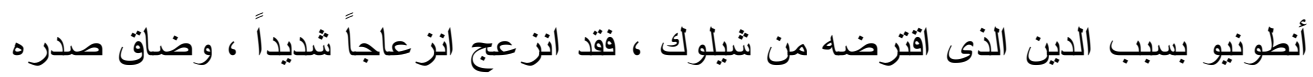

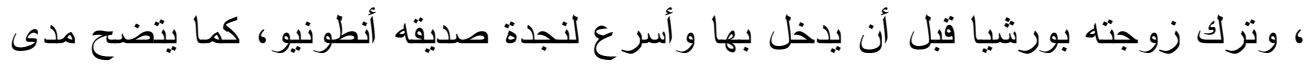


أصالة ووفاء زوجته بورشيا التى شجعته أن يتركها فى ليلة زفافها ويهرول لنجدة صديقة ،

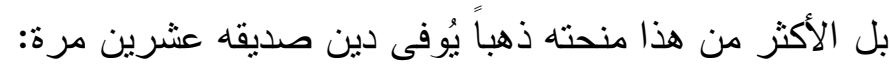
بورشيا : ... إذ كيف أرضى أن تضاجعني بنفس قلقة!؟ .. ولسوف تحمل فى يدك ذهباً يُوفى دينه عشرين مرة ، وبعد أن تُؤديه عُد وصاحبك الأمين! . .. أما أنا

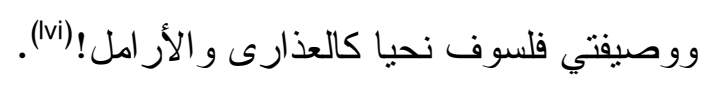

كما أن باسانيو يعرض على هيئة المحكمة أن يدفع عشرة أمثال المبلغ أو تُقَعُ رأســهـ ويداه وقلبه بدلاً من صديقه أنطونيو : بعرضي علئ

باسانيو:... أتعهد أن أدفع عشرة أمثال المبلغ أو تقطع رأسى ويداى وقلبى!(vii)

\section{قيمة القناعة}

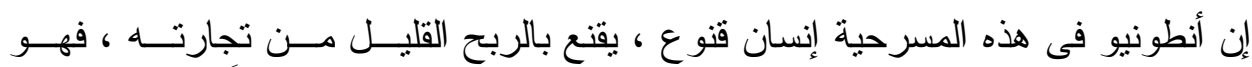

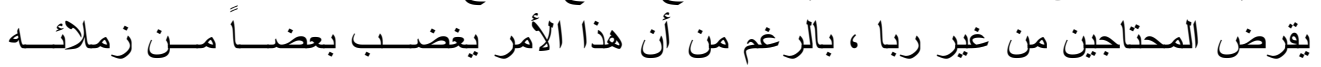
التجار :

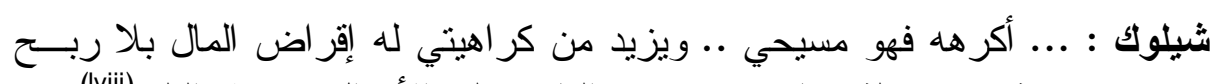

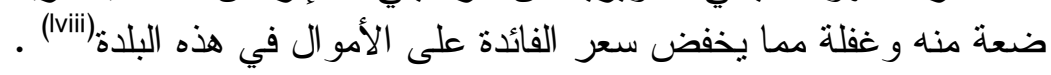

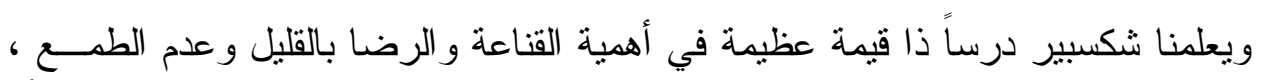

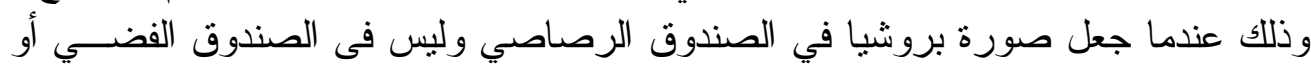

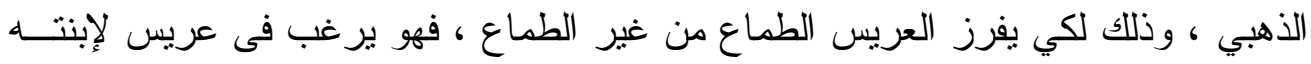

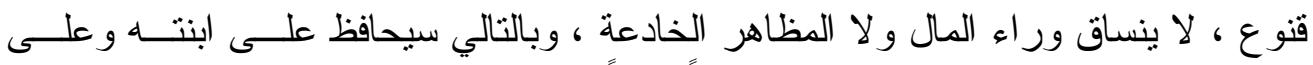

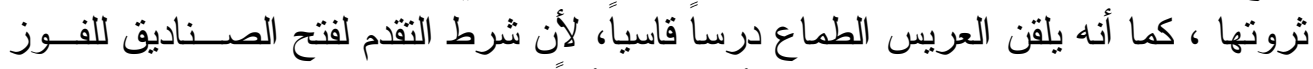

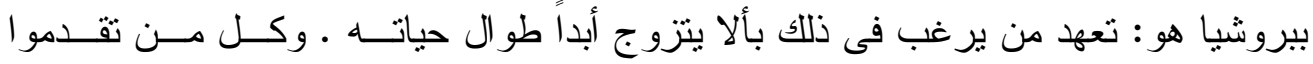

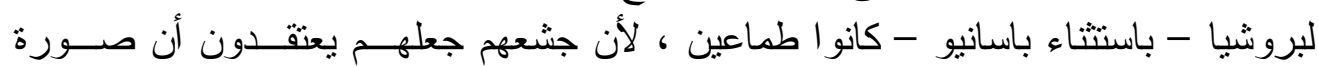

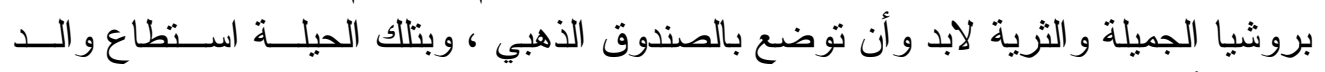
بورشيا أن يبعد ابنته عن الرجال الطماعين:

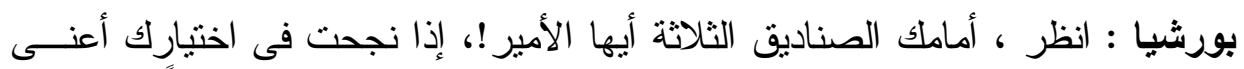

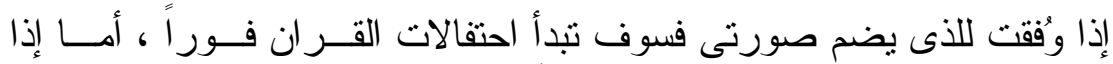

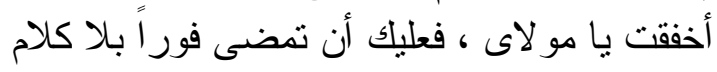

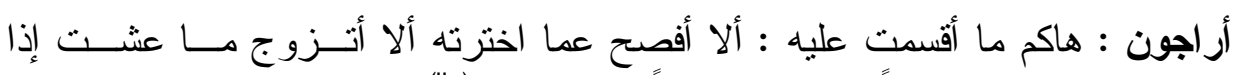

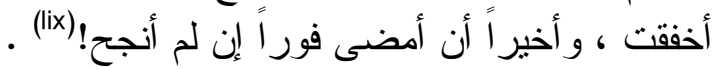


وبعد أن يختار باسانيو الصندوق الصائب تغمره سعادة كبيرة ، كما تغمر بورشيا سعادة أنساة

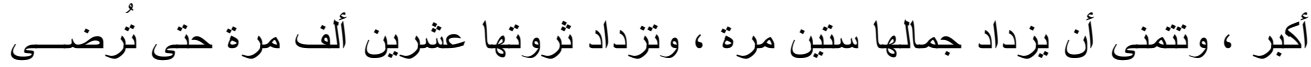

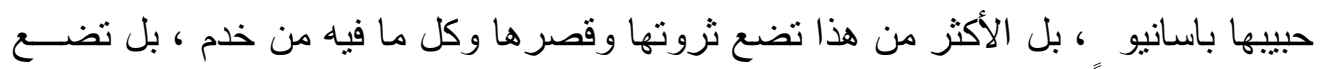

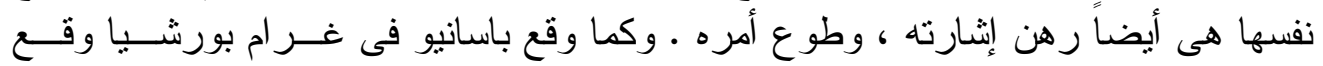

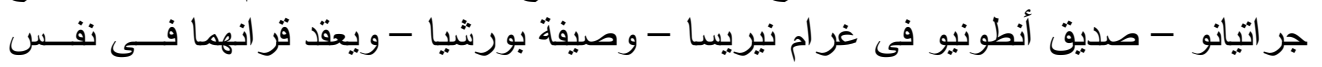

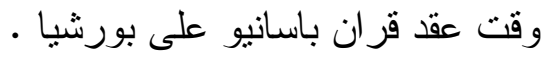

\section{قيمة الشرف فى مسرحية تاجر البندقية}

تتجلى هذه القيمة فى الصفات التى بتحلى بها كلا من أنطونيو وباسانيو ، فباسانيو إنسان

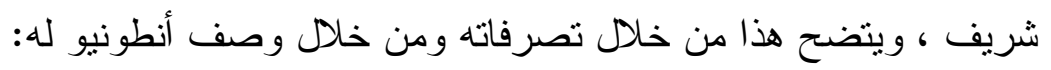

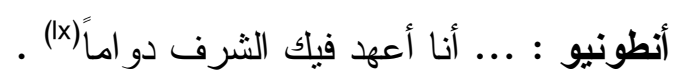

كما أن أنطونيو يتمتع بهذه القيمة أيضاً ، فكل أهالى مدينة البندقية يقولون عنه أنه شريف و أمين:

$$
\text { سولآيو : ... هو أن أنطونيو الثريف و الأمين (xii) }
$$

ونرى مدى حرص باسانيو على قيمة الثرف وأهميته عند الإنسان ، وهذا و اضح من كن النه

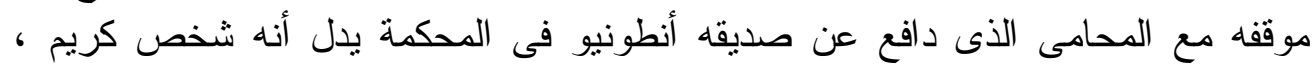

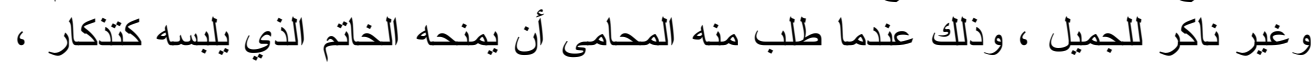

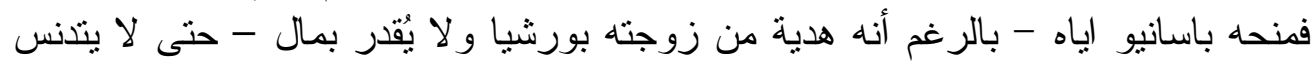
شرفه بالنكر ان: - (بانيان

باسانيو : ... إنى أجبرت على إرسال الخاتم فى أثره بعد الإحساس بوخز العار

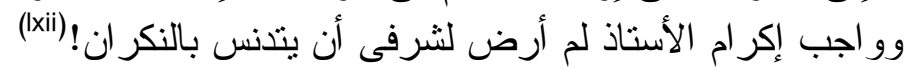

\section{فضيلة "الرحمة" فى مسرحية "تاجر البندقية"}

الرحمن الرحيم ، اسمان من أسماء الله الحسنى ، و الرحمن يحض البشرية على الرحمة

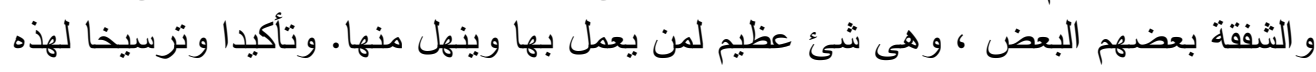

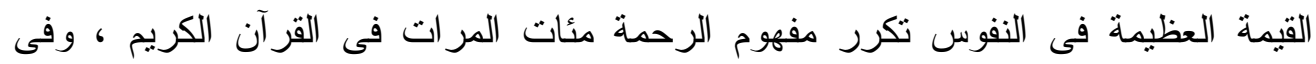

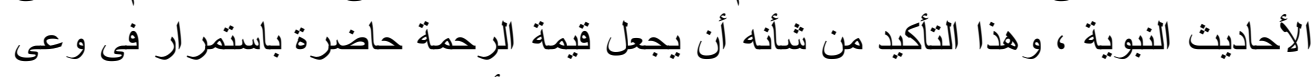

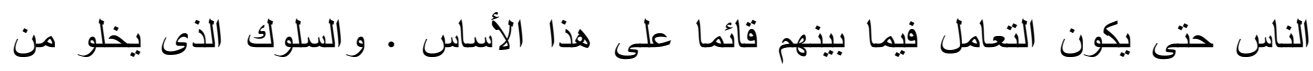

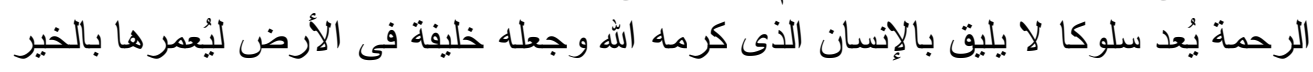

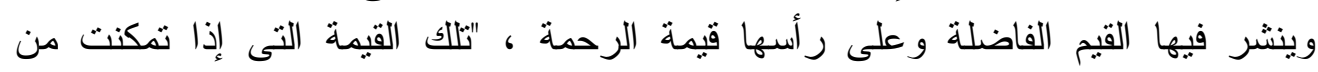

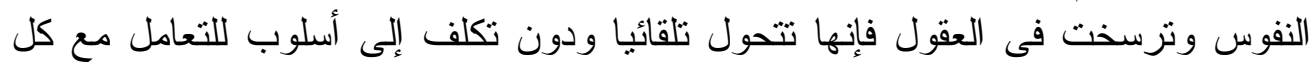


الكائنات. وتمثل الرحمة أرقى درجات السمو الأخلاقي الإنساني ، لأن هذا السلوك مرتبط

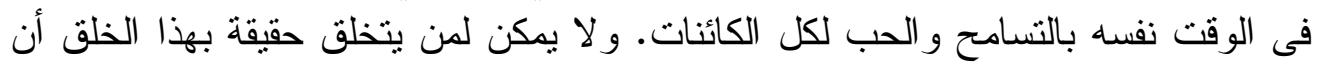

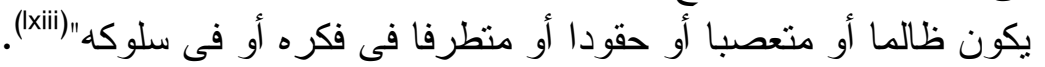

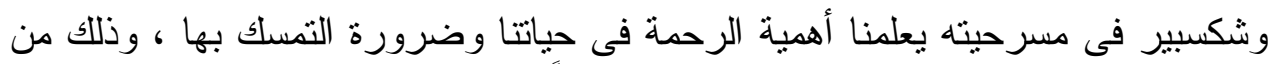

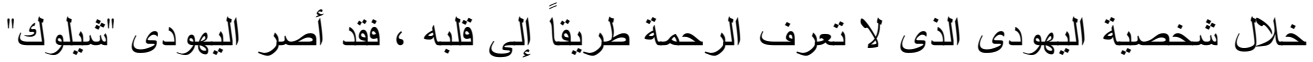

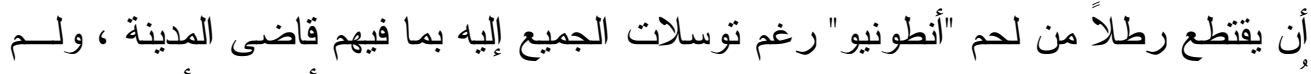

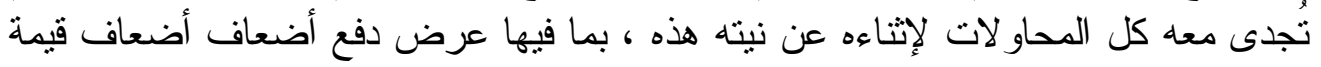

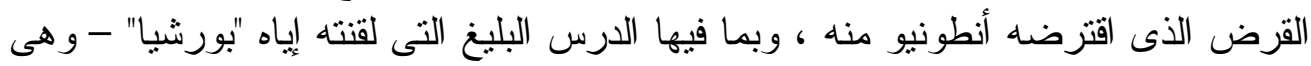

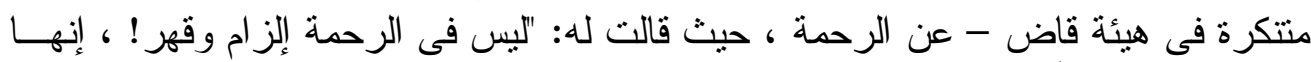

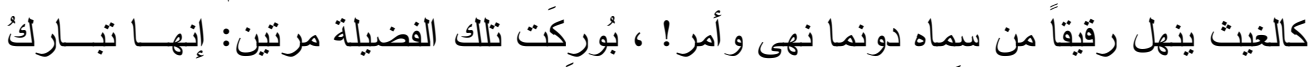

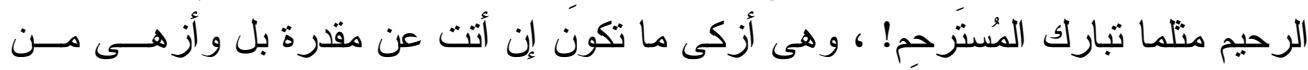

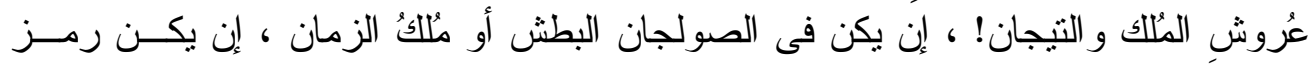

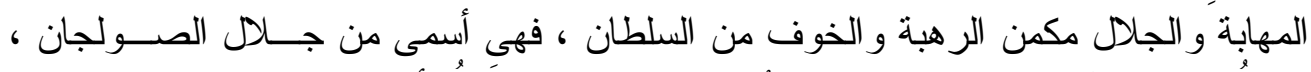

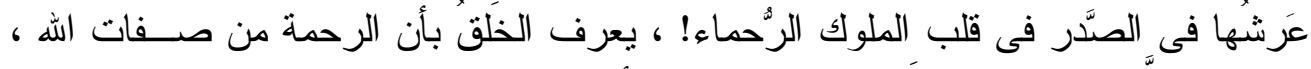

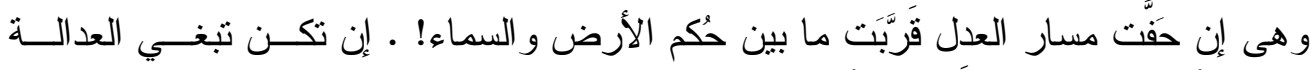

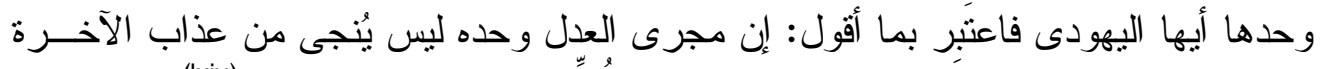

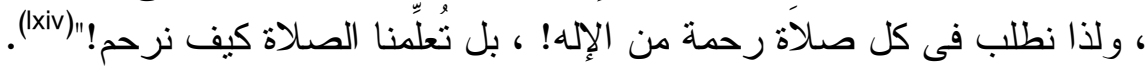

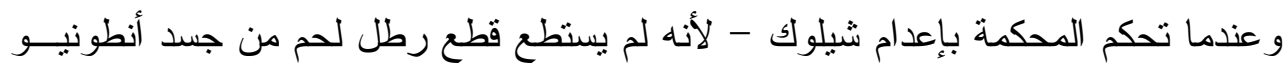

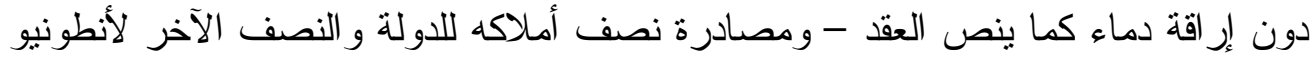

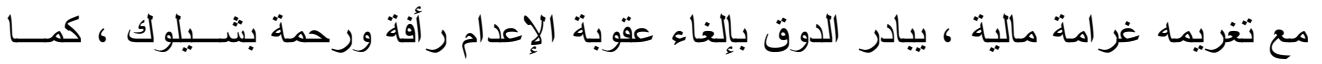

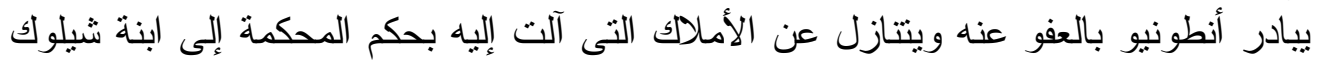

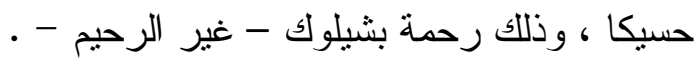

لقد نجح شكسبير فى تعليمنا ضرورة وقيمة فضيلة الرحمة فى حياة البشر عن طريق تأكيــد

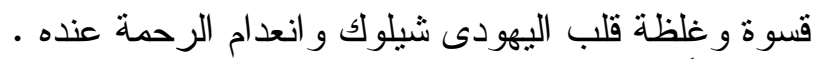




\section{نتائج الار اسة}

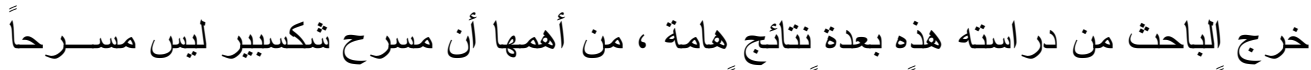

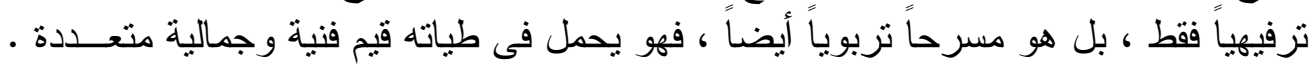

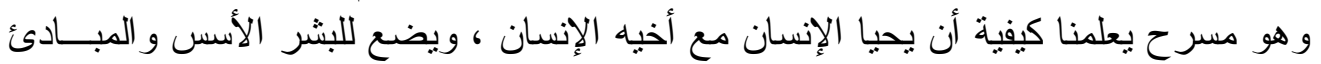

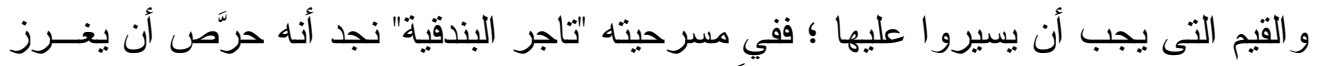

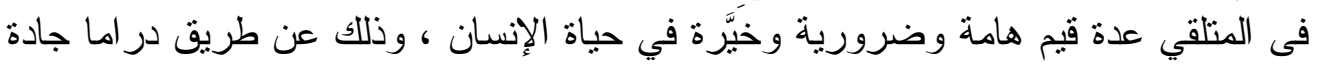

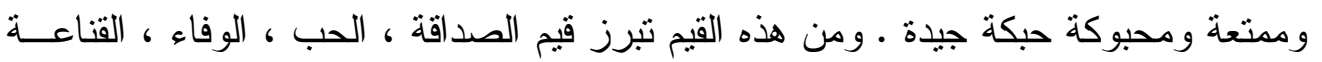
، الشرف ، بالإضافة إلى فضيلة الرحمة. فعلى سبيل هذه المثنال:

- بدأ شكسبير مسرحيته "تاجر البندقية" بالحزن و الكآبة ، فالبطل "أنطونيو" يشعر بــالحزن

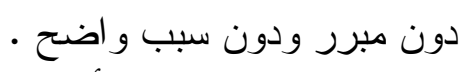

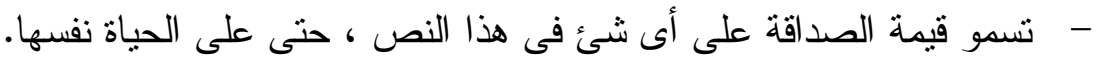

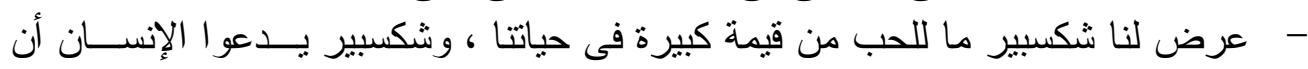
بحب أخيه الإنسان.

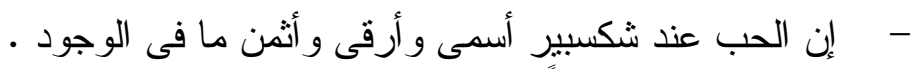

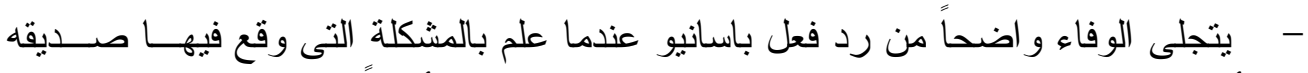

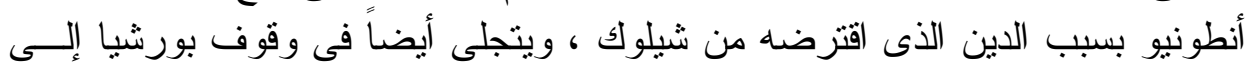
جانب صديق زوجها.

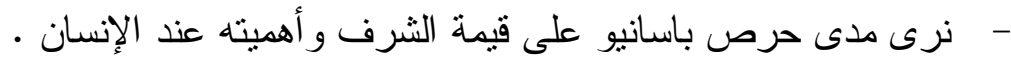

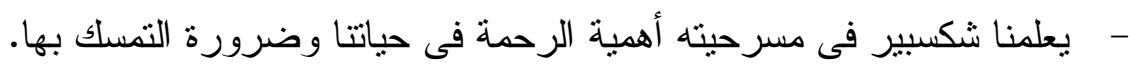




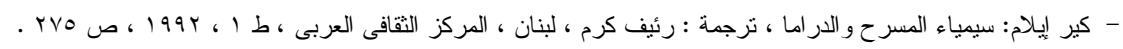

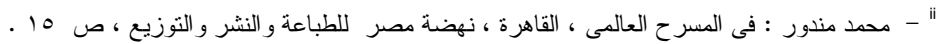

- - iii

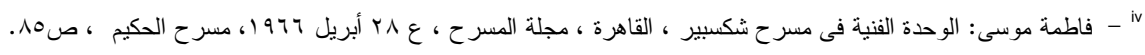

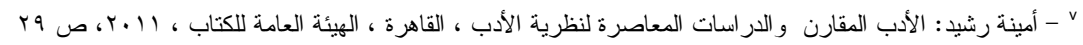

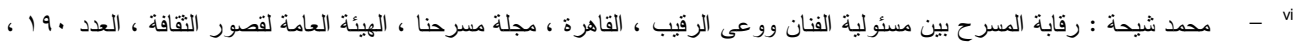

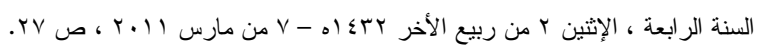

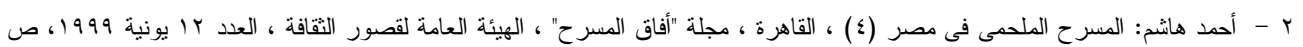
. TVT

loV viii

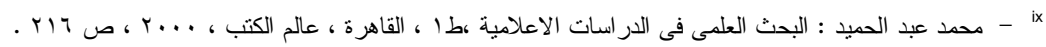

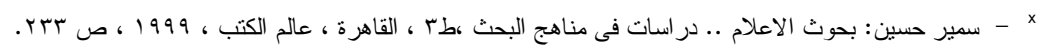

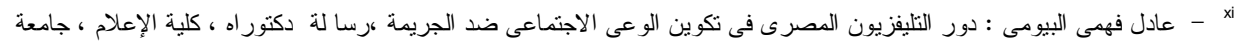

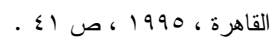

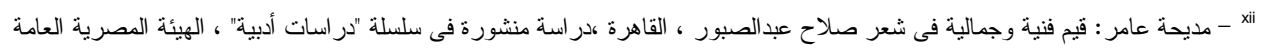

xiii - - ar.wikipedia.org/wiki/

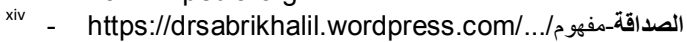

vv sudaneseonline.com/cgi-bin/sdb/rbb.cgi?seq=msg\&board=^• ...

xvi - ar.wikipedia.org/wiki/

xvii - www.madinagate.com/rvo/....

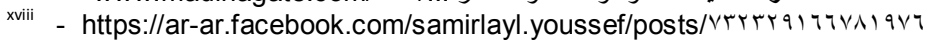

xix - ar.islamway.net > المقالات > القناعة

1-William Shakespeare : HAMLET, New Delhi, RAMA BROTHERS, Ninth Edition, $1997, \mathrm{p}$ ).

○- William Shakespeare : King Henry IV, New Delhi, S. CHAND \& CO,

RAM NAGAR, 19v , p XV

xxii - 1-William Shakespeare : HAMLET, New Delhi, RAMA BROTHERS Ninth Edition, 1997, pag

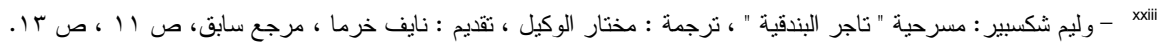
xxiv

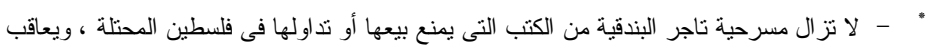

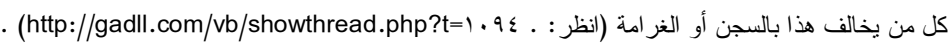

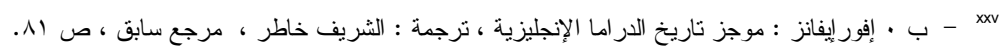

xxvi

xxvii

xxviii

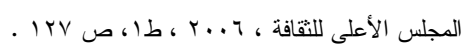

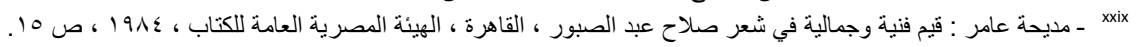

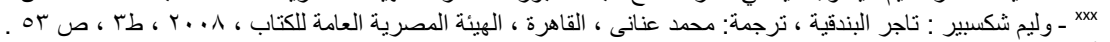
xxxi

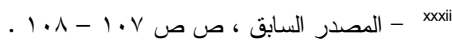

xxxiii

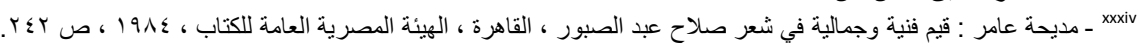
xxxv 
xxxvi

xxxvii

_ xxxviii

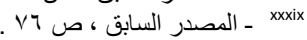

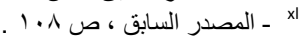

xli

Xlii

xliii

xliv

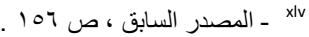

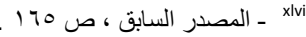

xlvii

Xlviii

llix

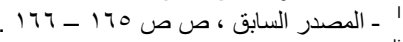

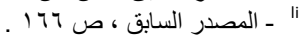

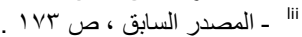

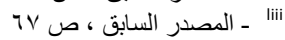

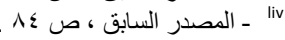

- IV

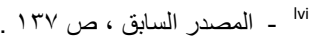

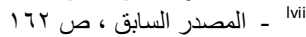

_ _ lviii

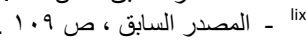

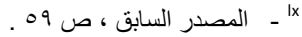

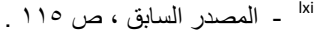

Ixii

|lxwii

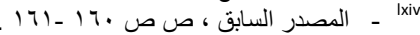

